\title{
Methanethiol, dimethyl sulfide and acetone over biologically productive waters in the southwest Pacific Ocean
}

\author{
Sarah J. Lawson ${ }^{1}$, Cliff S. Law ${ }^{2,3}$, Mike J. Harvey ${ }^{2}$, Thomas G. Bell ${ }^{4}$, Carolyn F. Walker ${ }^{2}$, Warren J. de Bruyn ${ }^{5}$, and \\ Eric S. Saltzman ${ }^{6}$ \\ ${ }^{1}$ Commonwealth Scientific and Industrial Research Organisation (CSIRO), Oceans and Atmosphere, Aspendale, Australia \\ ${ }^{2}$ National Institute of Water and Atmospheric Research (NIWA), Wellington, New Zealand \\ ${ }^{3}$ Department of Chemistry, University of Otago, Dunedin, New Zealand \\ ${ }^{4}$ Plymouth Marine Laboratory, Plymouth, UK \\ ${ }^{5}$ Schmid College of Science and Technology, Chapman University, Orange, California, USA \\ ${ }^{6}$ Earth System Science, University of California, Irvine, California, USA
}

Correspondence: Sarah J. Lawson (sarah_jane_lawson@yahoo.com.au)

Received: 25 September 2019 - Discussion started: 16 October 2019

Revised: 4 February 2020 - Accepted: 5 February 2020 - Published: 16 March 2020

\begin{abstract}
Atmospheric methanethiol $\left(\mathrm{MeSH}_{\mathrm{a}}\right)$, dimethyl sulfide $\left(\mathrm{DMS}_{\mathrm{a}}\right.$ ) and acetone (acetone $\mathrm{a}_{\mathrm{a}}$ ) were measured over biologically productive frontal waters in the remote southwest Pacific Ocean in summertime 2012 during the Surface Ocean Aerosol Production (SOAP) voyage. $\mathrm{MeSH}_{\mathrm{a}}$ mixing ratios varied from below the detection limit $(<10 \mathrm{ppt})$ up to $65 \mathrm{ppt}$ and were $3 \%-36 \%$ of parallel $\mathrm{DMS}_{\mathrm{a}}$ mixing ratios. $\mathrm{MeSH}_{\mathrm{a}}$ and $\mathrm{DMS}_{\mathrm{a}}$ were correlated over the voyage $\left(R^{2}=0.3\right.$, slope $\left.=0.07\right)$ with a stronger correlation over a coccolithophore-dominated phytoplankton bloom $\left(R^{2}=\right.$ 0.5, slope 0.13). The diurnal cycle for $\mathrm{MeSH}_{\mathrm{a}}$ shows similar behaviour to $\mathrm{DMS}_{\mathrm{a}}$ with mixing ratios varying by a factor of $\sim 2$ according to time of day with the minimum levels of both $\mathrm{MeSH}_{\mathrm{a}}$ and $\mathrm{DMS}_{\mathrm{a}}$ occurring at around 16:00 LT (local time, all times in this paper are in local time). A positive flux of MeSH out of the ocean was calculated for three different nights and ranged from 3.5 to $5.8 \mu \mathrm{mol} \mathrm{m}{ }^{-2} \mathrm{~d}^{-1}$, corresponding to $14 \%-24 \%$ of the DMS flux $(\mathrm{MeSH} /(\mathrm{MeSH}+\mathrm{DMS})$ ). Spearman rank correlations with ocean biogeochemical parameters showed a moderateto-strong positive, highly significant relationship between both $\mathrm{MeSH}_{\mathrm{a}}$ and $\mathrm{DMS}_{\mathrm{a}}$ with seawater DMS (DMS ${ }_{\mathrm{sw}}$ ) and a moderate correlation with total dimethylsulfoniopropionate (total DMSP). A positive correlation of acetone $e_{a}$ with water temperature and negative correlation with nutrient concentrations are consistent with reports of acetone production in warmer subtropical waters. Positive correlations of acetone ${ }_{\mathrm{a}}$
\end{abstract}

with cryptophyte and eukaryotic phytoplankton numbers, and high-molecular-weight sugars and chromophoric dissolved organic matter (CDOM), suggest an organic source. This work points to a significant ocean source of $\mathrm{MeSH}$, highlighting the need for further studies into the distribution and fate of $\mathrm{MeSH}$, and it suggests links between atmospheric acetone levels and biogeochemistry over the midlatitude ocean.

In addition, an intercalibration of $\mathrm{DMS}_{\mathrm{a}}$ at ambient levels using three independently calibrated instruments showed $\sim 15 \%-25 \%$ higher mixing ratios from an atmospheric pressure ionisation chemical ionisation mass spectrometer (mesoCIMS) compared to a gas chromatograph with a sulfur chemiluminescence detector (GC-SCD) and proton transfer reaction mass spectrometer (PTR-MS). Some differences were attributed to the $\mathrm{DMS}_{\mathrm{a}}$ gradient above the sea surface and differing approaches of integrated versus discrete measurements. Remaining discrepancies were likely due to different calibration scales, suggesting that further investigation of the stability and/or absolute calibration of DMS standards used at sea is warranted. 


\section{Introduction}

Volatile organic compounds (VOCs) are ubiquitous in the atmosphere, and they have a central role in processes affecting air quality and climate, via their role in formation of secondary organic aerosol and tropospheric ozone. The role of the ocean in the global cycle of several VOCs is becoming increasingly recognised, with recent studies showing that the ocean serves as a major source, sink, or both for many pervasive and climate-active VOCs (Law et al., 2013; Liss and Johnson, 2014; Carpenter and Nightingale, 2015).

The ocean is a major source of reduced volatile sulfur gases and the most well-studied of these is dimethyl sulfide (DMS) $\left(\mathrm{CH}_{3} \mathrm{SCH}_{3}\right)$, with a global ocean source of $\sim 28 \mathrm{Tg} \mathrm{S} \mathrm{a}^{-1}$ (Lee and Brimblecombe, 2016). Since the publication of the CLAW hypothesis (Charlson et al., 1987), which proposed a climate feedback loop between ocean DMS concentrations and cloud droplet concentrations and albedo, extensive investigations have been undertaken into DMS formation and destruction pathways, oceanatmosphere transfer, atmospheric transformation, and impacts on chemistry and climate (Law et al., 2013; Liss and Johnson, 2014; Carpenter et al., 2012; Quinn and Bates, 2011). Methanethiol or methyl mercaptan $(\mathrm{MeSH})\left(\mathrm{CH}_{3} \mathrm{SH}\right)$ is another reduced volatile organic sulfur gas which originates in the ocean, with a global ocean source estimated to be $\sim 17 \%$ of the DMS source (Lee and Brimblecombe, 2016). The MeSH ocean source is twice as large as the total of all anthropogenic sources (Lee and Brimblecombe, 2016). However, the importance of ocean-derived MeSH as a source of sulfur to the atmosphere, and the impact of $\mathrm{MeSH}$ and its oxidation products on atmospheric chemistry and climate, is not well understood.

DMS and MeSH in seawater $\left(\mathrm{DMS}_{\mathrm{sw}}\right.$ and $\left.\mathrm{MeSH}_{\mathrm{sw}}\right)$ are both produced from precursor dimethylsulfoniopropionate (DMSP), which is biosynthesised by different taxa of phytoplankton and released into seawater as a result of ageing, grazing or viral attack (Yoch, 2002). DMSP is then degraded by bacterial catabolism (enzyme-catalysed reaction) via competing pathways that produce either DMS or MeSH (Yoch, 2002). Recent research showed that the bacterium Pelagibacter can simultaneously catabolise both $\mathrm{DMS}_{\mathrm{sw}}$ and $\mathrm{MeSH}_{\mathrm{sw}}$ (Sun et al., 2016), although it is not known how widespread this phenomenon is. DMS may also be produced by phytoplankton that directly cleave DMSP into DMS (Alcolombri et al., 2015). Once released, $\mathrm{MeSH}_{\mathrm{sw}}$ and $\mathrm{DMS}_{\mathrm{sw}}$ undergo further reaction in seawater. These compounds may be assimilated by bacteria, converted to dissolved non-volatile sulfur, be photochemically destroyed, or, in the case of $\mathrm{MeSH}_{\mathrm{sw}}$, react with dissolved organic matter (DOM) (Kiene and Linn, 2000; Kiene et al., 2000; Flöck and Andreae, 1996). $\mathrm{MeSH}_{\mathrm{sw}}$ has a much higher loss rate constant than $\mathrm{DMS}_{\mathrm{sw}}$, with a lifetime of the order of minutes to an hour compared to approximately days for $\mathrm{DMS}_{\mathrm{sw}}$ (Kiene, 1996; Kiene and Linn, 2000). A fraction $(\sim 10 \%)$ of $\mathrm{DMS}_{\mathrm{sw}}$ ventilates to the atmosphere where it can influence particle numbers and properties through its oxidation products (Simó and Pedrós-Alió, 1999; Malin, 1997). The fraction of $\mathrm{MeSH}_{\mathrm{sw}}$ ventilating to the atmosphere is poorly constrained.

While $\mathrm{DMS}_{\mathrm{sw}}$ measurements are relatively widespread, only a few studies have measured $\mathrm{MeSH}_{\mathrm{sw}}$. During an Atlantic Meridional Transect cruise in 1998 (Kettle et al., 2001) $\mathrm{MeSH}_{\mathrm{sw}}$ was higher in coastal and upwelling regions with the ratio of $\mathrm{DMS}_{\mathrm{sw}}$ to $\mathrm{MeSH}_{\mathrm{sw}}$ varying from unity to 30. Leck and Rodhe (1991) also reported ratios of $\mathrm{DMS}_{\mathrm{sw}} / \mathrm{MeSH}_{\mathrm{sw}}$ of 16,20 and 6 in the Baltic Sea, Kattegat-Skagerrak, and North Sea, respectively. The drivers of this variability are unknown, but they are likely due to variation in the dominant bacterial pathway and/or spatial differences in degradation processes. More recent $\mathrm{MeSH}_{\mathrm{sw}}$ measurements in the northeast subarctic Pacific Ocean showed that the ratio of $\mathrm{DMS}_{\mathrm{sw}} / \mathrm{MeSH}_{\mathrm{sw}}$ varied from 2 to 5, indicating that $\mathrm{MeSH}_{\mathrm{sw}}$ was a significant contributor to the volatile sulfur pool in this region (Kiene et al., 2017). $\mathrm{MeSH}_{\mathrm{sw}}$ measurements from these three studies (Kettle et al., 2001; Leck and Rodhe, 1991; Kiene et al., 2017) were also used to calculate the ocean-atmosphere flux of MeSH, assuming control from the water side. The flux of MeSH / (MeSH + DMS) ranged from $4 \%$ to $5 \%$ in the Baltic Sea and Kattegat, and it was $11 \%$ in the North Sea (Leck and Rodhe, 1991), $16 \%$ over the North Atlantic-South Atlantic transect (Kettle et al., 2001 ) and $\sim 15 \%$ over the northeast subarctic Pacific (Kiene et al., 2017). In a review of global organo-sulfide fluxes, Lee and Brimblecombe (2016) estimated that ocean sources provide over half of the total global flux of MeSH to the atmosphere, with a total of $4.7 \mathrm{Tg} \mathrm{S} \mathrm{a}^{-1}$; however, this estimate is based on a voyage-average value from a single study in the North Atlantic-South Atlantic (Kettle et al., 2001) in which flux measurements varied by several orders of magnitude.

There are very few published atmospheric measurements of $\mathrm{MeSH}_{\mathrm{a}}$ over the ocean. To the best of our knowledge, the only prior $\mathrm{MeSH}_{\mathrm{a}}$ measurements over the ocean were made in 1986 over the Drake Passage and the coastal and inshore waters west of the Antarctic Peninsula (Berresheim, 1987). $\mathrm{MeSH}_{\mathrm{a}}$ was detected occasionally at up to $3.6 \mathrm{ppt}$, which was roughly $3 \%$ of the measured atmospheric $\mathrm{DMS}_{\mathrm{a}}$ levels (Berresheim, 1987).

Once $\mathrm{MeSH}_{\mathrm{sw}}$ is transferred from ocean to atmosphere $\left(\mathrm{MeSH}_{\mathrm{a}}\right)$, the main loss pathway for $\mathrm{MeSH}_{\mathrm{a}}$ is via reaction with $\mathrm{OH}$ and $\mathrm{NO}_{3}$ radicals. $\mathrm{MeSH}_{\mathrm{a}}$ reacts with $\mathrm{OH}$ at a rate 2-3 times faster than DMS, and as such $\mathrm{MeSH}_{\mathrm{a}}$ has an atmospheric lifetime of only a few hours (Lee and Brimblecombe, 2016). The oxidation pathways and products that result from $\mathrm{MeSH}_{\mathrm{a}}$ degradation are still highly uncertain (Lee and Brimblecombe, 2016; Tyndall and Ravishankara, 1991), though they may be somewhat similar to DMS (Lee and Brimblecombe, 2016). This leads to uncertainty around the final atmospheric fate of the sulfur emitted via MeSH and also the overall impact of $\mathrm{MeSH}_{\mathrm{a}}$ oxidation on atmospheric chem- 
istry, particularly in regions when MeSH is a significant proportion of total sulfur emitted.

In the case of acetone, positive fluxes from the ocean have been observed in biologically productive areas (Taddei et al., 2009) and over some subtropical ocean regions (Beale et al., 2013; Yang et al., 2014a; Tanimoto et al., 2014; Schlundt et al., 2017); however, in other subtropical regions, and generally in oligotrophic waters and at higher latitudes, net fluxes are zero (e.g. ocean and atmosphere in equilibrium) or negative (transfer of acetone into ocean) (Yang et al., 2014a, b; Marandino et al., 2005; Beale et al., 2015; Schlundt et al., 2017). Atmospheric acetone (acetone $a$ ) also has significant terrestrial sources including direct biogenic emissions from vegetation, oxidation of anthropogenic and biogenic hydrocarbons (predominantly alkanes), and biomass burning (Fischer et al., 2012). In the ocean, acetone $\mathrm{sw}_{\mathrm{sw}}$ is produced photochemically from chromophoric dissolved organic matter (CDOM), either directly by direct photolysis or via photosensitiser reactions (Zhou and Mopper, 1997; Dixon et al., 2013; de Bruyn et al., 2012; Kieber et al., 1990). There is also evidence of direct biological production by marine bacteria (Nemecek-Marshall et al., 1995) and phytoplankton (Schlundt et al., 2017; Sinha et al., 2007; Halsey et al., 2017). Furthermore, acetone ${ }_{s w}$ has been found to decrease with depth (Beale et al., 2015; Yang et al., 2014a; Beale et al., 2013; Williams et al., 2004), pointing to the importance of photochemistry and/or biological activity as the source. Studies have shown that acetone ${ }_{\text {sw }}$ production linked to photosynthetically active radiation (PAR) and net shortwave radiation (Sinha et al., 2007; Beale et al., 2015; Zhou and Mopper, 1997), and Beale et al. (2015) found higher acetone ${ }_{\text {sw }}$ concentrations in spring and summer compared to autumn and winter. Removal processes include uptake of acetone by bacteria as a carbon source (Beale et al., 2013, 2015; Halsey et al., 2017; Dixon et al., 2013), gas transfer into the atmosphere, vertical mixing into the deep ocean and photochemical destruction (Carpenter and Nightingale, 2015).

There are relatively few observations of acetone ${ }_{\mathrm{sw}}$ and acetone $_{\mathrm{a}}$ over the remote ocean, particularly in mid- and high-latitude regions. An understanding of the spatial distribution of acetone is particularly important due to the high degree of regional variation in the direction and magnitude of the acetone flux.

The Surface Ocean Aerosol Production (SOAP) voyage investigated the relationship between ocean biogeochemistry and aerosol and cloud processes in a biologically productive but under sampled region in the remote southwest Pacific Ocean (Law et al., 2017). In this work, we present measurements of $\mathrm{DMS}_{\mathrm{a}}, \mathrm{MeSH}_{\mathrm{a}}$ and acetone $\mathrm{a}$, including the largest observed mixing ratios of $\mathrm{MeSH}_{\mathrm{a}}$ in the marine boundary layer to date. We explore the relationship between $\mathrm{DMS}_{\mathrm{a}}, \mathrm{MeSH}_{\mathrm{a}}$ and acetone $\mathrm{a}$ as well as the relationship with ocean biogeochemical parameters. In particular, we investigate links between $\mathrm{MeSH}_{\mathrm{a}}$ and its precursor DMSP for the first time. We explore whether variability in acetone ${ }_{a}$ is linked to biogeochemistry, including warmer subtropical waters and organic precursors such as CDOM as has been reported elsewhere.

Given the large uncertainty in the oceanic budget of $\mathrm{MeSH}$, we estimate the importance of MeSH as a source of atmospheric sulfur in this region and compare results with other studies. Finally, we present results from a $\mathrm{DMS}_{\mathrm{a}}$ method comparison which was undertaken at sea between three independently calibrated measurement techniques.

\section{Method}

\subsection{Voyage}

The Surface Ocean Aerosol Production (SOAP) voyage took place on the NIWA RV Tangaroa over the biologically productive frontal waters of Chatham Rise $\left(44^{\circ} \mathrm{S}, 174-181^{\circ} \mathrm{E}\right)$, east of New Zealand in the southwest Pacific Ocean. The 23-day voyage took place during the austral summer in February-March 2012. The scientific aim was to investigate interactions between the ocean and atmosphere, and as such the measurement programme included comprehensive characterisation of ocean biogeochemistry, measurement of ocean-atmosphere gas and particle fluxes, and measurement of distribution and composition of trace gases and aerosols in the marine boundary layer (MBL) (Law et al., 2017). During the voyage, NASA MODIS ocean colour images and underway sensors were used to identify and map phytoplankton blooms. Three blooms were intensively targeted for measurement: (1) a dinoflagellate bloom with elevated Chl $a$, $\mathrm{DMS}_{\mathrm{sw}}$ and $p \mathrm{CO}_{2}$ drawdown, and high irradiance (bloom 1 - B1); (2) a coccolithophore bloom (bloom 2 - B2); and (3) a mixed community bloom of coccolithophores, flagellates, and dinoflagellates sampled before (bloom 3a-B3a) and after (bloom $3 b-B 3 b$ ) a storm. For further voyage and measurement details, see Law et al. (2017).

\subsection{PTR-MS}

A high-sensitivity proton transfer reaction mass spectrometer (PTR-MS) (Ionicon Analytik) was used to measure DMS, acetone and methanethiol. The PTR-MS sampled from a $25 \mathrm{~m} 3 / 8$ in. i.d. PFA (perfluoroalkoxy) inlet line, which drew air from the crow's nest of the vessel $28 \mathrm{~m}$ above sea level (a.s.l.) at $10 \mathrm{~L} \mathrm{~min}^{-1}$. A baseline switch based on relative wind speed and direction was employed to minimise flow of ship exhaust down the inlet (see Lawson et al., 2015).

The PTR-MS instrument parameters were as follows: inlet and drift tube temperature of $60^{\circ} \mathrm{C}$, a $600 \mathrm{~V}$ drift tube and 2.2 mbar drift tube pressure ( $\mathrm{E} / \mathrm{N}=133 \mathrm{Td}$, townsend). The $\mathrm{O}_{2}$ signal was $<1 \%$ of the primary ion $\mathrm{H}_{3} \mathrm{O}^{+}$signal. DMS, acetone and MeSH were measured at $m / z 63, m / z 59$ and $m / z 49$, respectively, with a dwell time of $10 \mathrm{~s}$. From dayof-year (DOY) 43-49, 19 selected ions including $\mathrm{m} / z 59$ and $m / z 63$ were measured, resulting in 17 mass scans per 
hour; however, from DOY 49 the PTR-MS measured in scan mode from $m / z 21$ to 155, allowing three full mass scans per hour. As such, MeSH measurements $(\mathrm{m} / \mathrm{z} 49)$ were made only from DOY 49 onward.

VOC-free air was generated using a platinum-coated glass wool catalyst heated to $350{ }^{\circ} \mathrm{C}$; four times per day this air was used to measure the background signal resulting from interference ions and outgassing of materials. An interpolated background signal was used for background correction. Calibrations of DMS and acetone were carried out daily by diluting calibration gas into VOC-free ambient air (Galbally et al., 2007). Calibration gases used were a custom $\sim 1 \mathrm{ppm}$ VOC mixture in nitrogen containing DMS and acetone (Scott Specialty Gases) and a custom $\sim 1$ ppm VOC calibration mixture in nitrogen containing acetone (Apel Riemer). The calibration gas accuracy was $\pm 5 \%$. A calibration gas for $\mathrm{MeSH}$ was not available during this voyage. The PTR-MS response to a given compound is dependent on the chemical ionisation reaction rate, defined by the collision rate constant and the mass dependent transmission of ions through the mass spectrometer. Given the similarity of the MeSH and DMS collision rate constants (Williams et al., 1998) and the very similar transmission efficiencies of $m / z 63$ and $m / z$ 49, we applied the empirically derived PTR-MS response factor for DMS $(m / z 63)$ to the MeSH signal at $m / z$ 49. The instrument response to DMS and acetone varied by $2 \%$ and $5 \%$ throughout the voyage, respectively.

In this work $m / z 59$ is assumed to be dominated by acetone. Propanal could also contribute to $\mathrm{m} / \mathrm{z} 59$, although studies suggest that this signal is likely low (Beale et al., 2013; Yang et al., 2014a). Similarly, $m / z 49$ has been attributed to MeSH, based on a literature review (Feilberg et al., 2010; Sun et al., 2016), and a lack of likely other contributing species at $m / z 49$ in the MBL. As such $m / z 59$ and $m / z 49$ represent an upper limit for acetone and $\mathrm{MeSH}$, respectively.

The minimum detectable limit for a single $10 \mathrm{~s}$ measurement of a selected mass was determined using the principles of ISO 6879 (ISO, 1995). Average detection limits for the entire voyage were as follows: $m / z 59$ (acetone), $24 \mathrm{ppt}$; $\mathrm{m} / z 63$ (DMS), $22 \mathrm{ppt}$; and $\mathrm{m} / \mathrm{z} 49$ (MeSH), 10 ppt. The percentages of $10 \mathrm{~s}$ observations above detection limits were as follows: $m / z$ 59, $100 \% ; m / z 63,98 \%$; and $m / z 49,63 \%$. Inlet losses were determined to be $<2 \%$ for isoprene, monoterpenes, methanol and DMS. Acetone and MeSH losses were not determined during the voyage; however, acetone inlet losses were tested previously using a parts-per-billion level mixture of calibration gases with PFA inlet tubing and found to be $<5 \%$. MeSH has a similar structure and physical properties to DMS at $\mathrm{pH}<10$ (Sect. 3.2), and so inlet losses are likely to be similar. These small $(<5 \%)$ losses could lead to a small underestimation in reported mixing ratios of $\mathrm{DMS}_{\mathrm{a}}$, acetone ${ }_{\mathrm{a}}$ and $\mathrm{MeSH}_{\mathrm{a}}$.

\subsection{DMS intercomparison}

During the SOAP voyage, $\mathrm{DMS}_{\mathrm{a}}$ measurements were made using three independently calibrated instruments: atmospheric pressure ionisation chemical ionisation mass spectrometer (mesoCIMS) from the University of California Irvine (UCI) (Bell et al., 2013, 2015), an Ionicon PTR-MS operated by the Commonwealth Scientific and Industrial Research Organisation (CSIRO) (Lawson et al., 2015) and a HP gas chromatograph with sulfur chemiluminescence detector (GC-SCD) operated by the National Institute of Water and Atmospheric Research (NIWA) (Walker et al., 2016).

Details of the mesoCIMS and GC-SCD measurement systems are provided by Bell et al. (2015) and Walker et al. (2016) with a brief description provided here. The mesoCIMS instrument (Bell et al., 2013) ionises DMS to DMS-H ${ }^{+} ; m / z=63$ ) by atmospheric pressure proton transfer from $\mathrm{H}_{3} \mathrm{O}^{+}$by passing a heated air stream over a radioactive nickel foil (Ni-63). The mesoCIMS drew air from the eddy covariance set-up on the bow mast at approximately $12 \mathrm{~m}$ a.s.1. The inlet was a $1 / 2$ in. i.d. PFA tube with a total inlet length of $19 \mathrm{~m}$ and a turbulent flow at $90 \mathrm{slpm}$ (standard litres per minute). The mesoCIMS subsampled from the inlet at $1 \mathrm{~L} \mathrm{~m}^{-1}$. A gaseous tri-deuterated DMS standard (D3DMS) was added to the air sample stream at the entrance to the inlet. The internal standard was ionised and monitored continuously in the mass spectrometer at $m / z=66$, and the atmospheric DMS mixing ratio was computed from the measured 63/66 ratio. The internal standard was delivered from a high-pressure aluminium cylinder and calibrated against a DMS permeation tube prior to and after the cruise (Bell et al., 2015).

The GC-SCD system included a semiautomated purge and trap system, a HP 6850 gas chromatograph with cryogenic pre-concentrator and thermal desorber, and sulfur chemiluminescence detection (Walker et al., 2016). The system was employed during the voyage for discrete DMS seawater measurements and gradient flux measurement bag samples (Smith et al., 2018). The system was calibrated using an internal methylethylsulfide (MES) permeation tube and external DMS permeation tube located in a Dynacalibrator ${ }^{\circledR}$ with a twice daily five-point calibration and a running standard every 12 samples (Walker et al., 2016).

A DMS measurement intercomparison between the mesoCIMS, GC-SCD and PTR-MS was performed during the voyage on DOY 64 and DOY 65. Tedlar bags (70 L) with blackout polythene covers were filled with air containing DMS at sub-parts-per-billion levels, and they were sequentially distributed between all instruments for analysis within a few hours. On DOY 64, two bags were prepared including ambient air filled from the foredeck and a DMS standard prepared using a permeation device (Dynacalibrator) and dried compressed air (DMS range 384-420 ppt from permeation uncertainty). On DOY 65, two additional bags were prepared including one ambient air sample from the 
foredeck with tri-deuterated DMS added and a DMS standard prepared using the Dynacalibrator and dried compressed air (DMS range 331-363 ppt). MesoCIMS values are not available for DOY 64 due to pressure differences between bag and instrument calibration measurements; this was resolved by using an internal standard on DOY 65. For those analyses, the mesoCIMS and PTR-MS measured DMS at $m / z 63$ and tri-deuterated DMS at $m / z$ 66, while the GC-SCD measured both DMS and deuterated DMS as a single peak.

\subsection{Biogeochemical measurements in surface waters}

Continuous seawater measurements were obtained from surface water sampled by an intake in the vessel's bow at a depth of $\sim 7 \mathrm{~m}$ during the SOAP voyage and included underway temperature and salinity (Sea-Bird thermosalinograph SBE-21), underway chlorophyll $a$ (Chl $a$ ) and backscatter (Wetlabs (Sea-Bird) ECOtriplet), and dissolved DMS $\left(\mathrm{DMS}_{\mathrm{sw}}\right)$ (miniCIMS) (Bell et al., 2015). Quenching obscured the Chl $a$ signal during daylight when irradiance was $>50 \mathrm{~W} \mathrm{~m}^{-2}$.

The following parameters were measured in surface waters (depths 2-10 m) in discrete samples from Niskin bottles on a conductivity-temperature-depth (CTD) rosette: nutrients according to methods described in Law et al. (2011), particulate nitrogen concentration (Nodder et al., 2016), phytoplankton speciation, groups and numbers (optical microscopy of samples preserved in Lugol's solution) (Safi et al., 2007), and flow cytometry (Hall and Safi, 2001). In addition, the organic parameters measured included high-molecular-weight (HMW) reducing sugars (Somogyi, 1926, 1952; for details see Burrell, 2015), DMSP (Walker et al., 2016) and CDOM measured using a liquid waveguide capillary cell (Gall et al., 2013). See Table $S 1$ for measurement specifications and Law et al. (2017) for further details and results for these parameters.

\section{Results and discussion}

\subsection{DMS atmospheric intercalibration}

This section describes a comparison of $\mathrm{DMS}_{\mathrm{a}}$ measurements from bag samples of ambient air and DMS standard mixtures (analysed by GC-SCD, PTR-MS and mesoCIMS; see Sect. 2), as well as comparison of ambient $\mathrm{DMS}_{\mathrm{a}}$ measurements (PTR-MS and mesoCIMS).

\subsubsection{Comparison of bag samples}

Table 1 summarises the comparison between the GC-SCD, PTR-MS and mesoCIMS instruments for ambient and DMS standard bags prepared and analysed on DOY 64 and 65 (see Sect. 2.2). The highest DMS levels were measured by the mesoCIMS, with GC-SCD and PTR-MS being $~ 20 \%-$ $25 \%$ and $\sim 20 \%-30 \%$ lower, respectively. The GC-SCD and PTR-MS agreed reasonably well, with a mean difference of $5 \%$ (range $0 \%-10 \%$ ) between instruments for different diluted standard and ambient air bags. There was no clear influence of dry versus humid (ambient) bag samples on the differences between instruments.

\subsubsection{Comparison of in situ ambient measurements}

Measurements from the PTR-MS and mesoCIMS were interpolated to a common time stamp for comparison, and differences were examined only where data were available for both instruments. PTR-MS results for DMS were reported for $10 \mathrm{~s}$ every $4 \mathrm{~min}$ until DOY 49 and then $10 \mathrm{~s}$ every $20 \mathrm{~min}$ until the end of the voyage (Sect. 2.2). The mesoCIMS measured DMS continuously and reported 10 min averages. As such the PTR-MS measured only a "snapshot" of the DMS levels in each measurement cycle of 4 or $20 \mathrm{~min}$. This was a potential source of difference between the two instruments when DMS levels changed rapidly (Bell et al., 2015).

The mesoCIMS was deployed primarily for DMS eddy covariance measurements, while the PTR-MS was deployed to measure atmospheric mixing ratios of a range of VOCs. As such, the mesoCIMS was situated on the foredeck and sampled from the eddy covariance set-up on the bow mast (12 $\mathrm{m}$ a.s.1.), while the PTR-MS was sited further back in the vessel and sampled from the crow's nest ( $28 \mathrm{~m}$ a.s.1.). Therefore, due to different intake heights, a further source of the difference between the PTR-MS and mesoCIMS measurements is likely due to vertical gradients in DMS caused by turbulent mixing of the local surface DMS flux into the atmospheric surface layer. On days with a strong DMS source and/or more stable stratification in the boundary layer, a significant decrease with height is expected (Smith et al., 2018). If all the DMS observed was due to local emissions, the vertical gradient would be described by Eq. (2) from Smith et al. (2018):

$F \equiv-u^{*} C^{*}=-\frac{u^{*} k}{\varphi c(z / L)}\left(\frac{\partial C}{\partial \ln z}\right)$,

where $u^{*}$ is friction velocity, $C^{*}$ is scaling parameter for gas concentration, $k$ is the von Kármán constant, $\varphi c$ is the stability function for mass, $z$ is the height above mean water level and $L$ is the Monin-Obukhov scaling length representing atmospheric stability. Atmospheric stability is a measure of the degree of vertical motion in the atmosphere, where $z / L=0$ indicates neutral stability, $z / L>0$ indicates a stable atmosphere and $z / L<0$ indicates an unstable atmosphere.

Figure 1 shows wind speed, absolute wind direction and atmospheric stability, $\mathrm{DMS}_{\mathrm{a}}$ levels from the voyage measured by PTR-MS and mesoCIMS, relative percent difference between the two measurements (normalised to the mesoCIMS), and observed absolute difference in $\mathrm{DMS}_{\mathrm{a}}$ between the two measurements, as well as the expected calculated difference (Eq. 1) between the two measurements due to the $\mathrm{DMS}_{\mathrm{a}}$ concentration gradient. 
Table 1. Results of the DMS bag sample intercomparison study undertaken during the SOAP voyage. Note that a $1 \mathrm{~s}$ PTR-MS dwell time for $m / z 63$ and $m / z 66$ was used during the intercomparison compared to the $10 \mathrm{~s}$ during ambient measurements; as such, the PTR-MS standard deviation reported here is expected to be $\sim 3$ times higher than during ambient measurements. "Total" refers to the ambient DMS + spiked tri-deuterated DMS bag sample on DOY 65.

\begin{tabular}{llrrr|rrr}
\hline & & \multicolumn{3}{c|}{ DMS (ppt) average \pm SD } & \multicolumn{3}{c}{ DMS ratios } \\
\cline { 3 - 8 } DOY & Comparison & GC-SCD & PTR-MS & mesoCIMS & $\begin{array}{r}\text { GC-SCD / } \\
\text { PTR-MS }\end{array}$ & $\begin{array}{r}\text { PTR-MS / } \\
\text { mesoCIMS }\end{array}$ & $\begin{array}{r}\text { GC-SCD / } \\
\text { mesoCIMS }\end{array}$ \\
\hline 64 & Standard (dry) & $354 \pm 6$ & $339 \pm 64$ & $\mathrm{n} / \mathrm{a}$ & $1.04 \pm 0.2$ & $\mathrm{n} / \mathrm{a}$ & $\mathrm{n} / \mathrm{a}$ \\
65 & Standard (dry) & $289 \pm 2$ & $262 \pm 43$ & $383 \pm 30$ & $1.1 \pm 0.18$ & $0.68 \pm 0.12$ & $0.75 \pm 0.06$ \\
\hline 64 & Ambient & $168 \pm 5$ & $158 \pm 49$ & $\mathrm{n} / \mathrm{a}$ & $1.06 \pm 0.33$ & $\mathrm{n} / \mathrm{a}$ & $\mathrm{n} / \mathrm{a}$ \\
65 & Ambient & $\mathrm{n} / \mathrm{a}$ & $127 \pm 43$ & $141 \pm 5$ & $\mathrm{n} / \mathrm{a}$ & $0.90 \pm 0.30$ & $\mathrm{n} / \mathrm{a}$ \\
& +Tri-deuterated DMS & $\mathrm{n} / \mathrm{a}$ & $197 \pm 49$ & $260 \pm 2$ & $\mathrm{n} / \mathrm{a}$ & $0.76 \pm 0.19$ & $\mathrm{n} / \mathrm{a}$ \\
\hline & Total & $323 \pm 9$ & $324 \pm 66$ & $401 \pm 6$ & $1.0 \pm 0.2$ & $0.81 \pm 0.16$ & $0.81 \pm 0.03$ \\
\hline
\end{tabular}
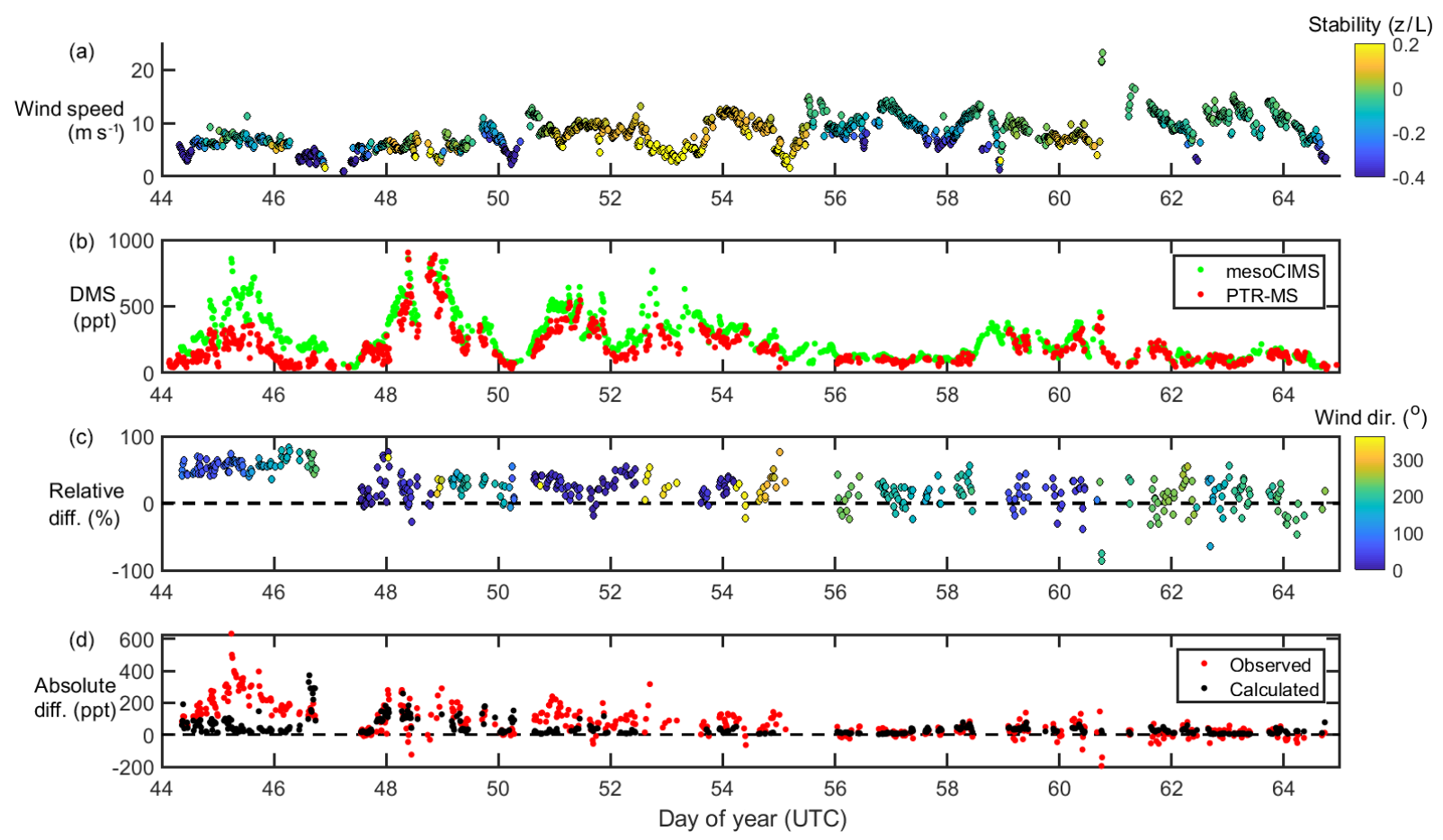

Figure 1. From top to bottom, wind speed and stability (a), DMS $\mathrm{a}_{\mathrm{a}}$ measurements from mesoCIMS and PTR-MS (b), relative difference (normalised to mesoCIMS) according to absolute wind direction (c), and absolute observed and calculated difference between mesoCIMS and PTR-MS (d), taking into account the expected DMS concentration gradient (Eq. 1).

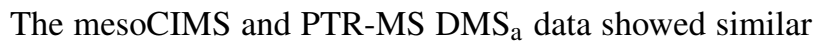
temporal behaviour over the voyage (Fig. 1). From DOY 44 to 46 there was an average of $50 \%( \pm 10 \%)$ relative difference between measurements, yet on DOY 47 this difference decreased suddenly to an average of $\sim 20 \%( \pm 20 \%)$.

Overall, agreement between instruments improved with time during the voyage, with differences of several hundred parts per trillion (ppt) of DMS observed in the first few days decreasing to differences of only 10-20 ppt by the end of the voyage. The agreement between instruments improves with increasing wind speeds (Fig. 1). The expected calculated difference between $\mathrm{DMS}_{\mathrm{a}}$ at the two inlet heights due to the DMS concentration gradient also decreases throughout the voyage. This indicates that the increasing agreement between instruments during the voyage was likely influenced by a progressively well-mixed atmosphere leading to weaker DMS vertical gradients.

The reason for the improved agreement between mesoCIMS and PTR-MS at DOY 47 is unlikely due to a decrease in the DMS concentration gradient (Fig. 1d, bottom 

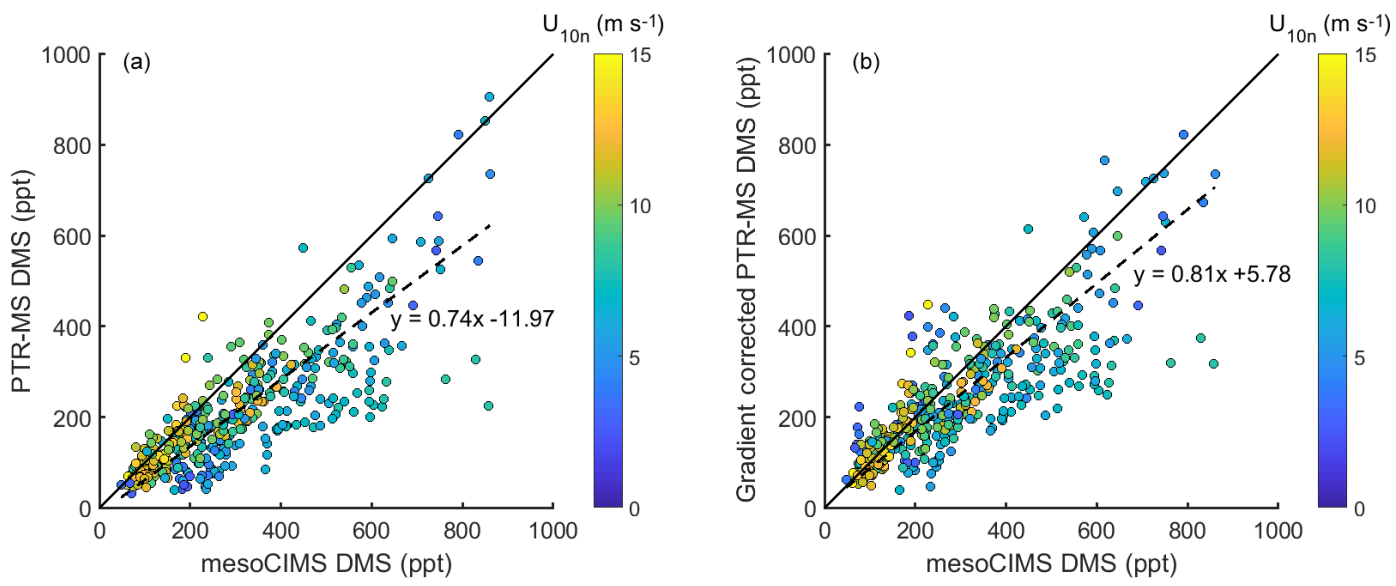

Figure 2. (a) DMS $\mathrm{D}_{\mathrm{a}}$ measured by mesoCIMS ( $x$ axis) and PTR-MS ( $y$ axis) (b) mesoCIMS ( $x$ axis) and PTR-MS ( $y$ axis) DMS data corrected for the expected concentration gradient (observed PTR-MS DMS + calculated delta DMS). Dashed lines represent the reduced major axis regression and solid lines represent a $1: 1$ relationship.

panel), but it is more likely due to changes in instrument calibration or other differences. However, careful inspection of the instrument parameters, configurations and calibration responses prior to DOY 47 did not identify the cause of the disagreement.

Figure 2a shows paired $\mathrm{DMS}_{\mathrm{a}}$ data from the mesoCIMS versus PTR-MS over the whole voyage, and Fig. $2 b$ shows paired mesoCIMS data versus PTR-MS data converted to the same height as the mesoCIMS with the expected DMS difference calculated from the eddy covariance estimate of DMS flux (from mesoCIMS) and eddy diffusivity (PTRMS DMS heights). The reduced major axis regression relationship between the two measurement systems for uncorrected data gives a slope of $0.74 \pm 0.02$, while for the corrected data the relationship gives $0.81 \pm 0.02\left(R^{2}=0.69\right)$. The gradientcorrected slope agrees with the ambient bag sample ratio from the method comparison (PTR-MS / mesoCIMS = $0.81 \pm 0.16$ ) (Table 1). Correcting for the DMS gradient improved the comparison between PTR-MS and mesoCIMS. The remaining $\sim 20 \%$ difference is likely due to instrument calibration differences and differing approaches of integrated versus discrete measurements.

There was no obvious impact of absolute wind direction on the differences observed between measurement systems. Note that due to the baseline switch which was employed to avoid sampling ship exhaust down the PTR-MS inlet (Lawson et al., 2015), the PTR-MS did not sample during certain relative wind directions. However, this does not affect the comparison which was undertaken only when data were available for both instruments.

\subsection{Ambient atmospheric data}

Atmospheric mixing ratios of $\mathrm{MeSH}_{\mathrm{a}}, \mathrm{DMS}_{\mathrm{a}}$ and acetone $\mathrm{a}$ are shown along the voyage track in Fig. 3 with bloom loca-
Table 2. $\mathrm{MeSH}_{\mathrm{a}}, \mathrm{DMS}_{\mathrm{a}}$ and acetone $\mathrm{a}$ measured with PTR-MS during the SOAP voyage, with reaction rate constant for $\mathrm{OH}$ and calculated lifetime with respect to $\mathrm{OH}$.

\begin{tabular}{llrr}
\hline & $\begin{array}{l}\text { Mean } \\
\text { range (ppt) }\end{array}$ & $\begin{array}{r}k_{\mathrm{OH}^{*}}\left(\mathrm{~cm}^{3}\right. \\
\text { molecule }\end{array}$ & $\begin{array}{r}\text { Lifetime } \\
\text { (days) }\end{array}$ \\
\hline MeSH & $18(\mathrm{BDL}-65)$ & $3.40 \times 10^{-11}$ & 0.4 \\
DMS & 208 (BDL-957) & $1.29 \times 10^{-11}$ & 1 \\
Acetone & 237 (54-1508) & $2.20 \times 10^{-13}$ & 60 \\
\hline
\end{tabular}

BDL represents below detection limit. * Reaction rate constants from Atkinson (1997) (MeSH), Berresheim et al. (1987) (DMS) and Atkinson (1986) (acetone).

tions highlighted. Figure 4 shows a time series of $\mathrm{MeSH}_{\mathrm{a}}$, $\mathrm{DMS}_{\mathrm{a}}$, acetone $\mathrm{a}_{\mathrm{a}}$ and $\mathrm{MeSH}_{\mathrm{a}} / \mathrm{DMS}_{\mathrm{a}}$ (all measured with PTR-MS), as well as $\mathrm{DMS}_{\mathrm{sw}}$ (miniCIMS) from Bell et al. (2015), Chl $a$, irradiance, wind speed, wind direction, and sea and air temperature. Note that $\mathrm{MeSH}_{\mathrm{a}}$ measurements started on DOY 49 (the last day of bloom B1). The fraction of backward trajectories arriving at the ship that had been in contact with land masses in the previous 10 days is also shown with a value of 0 indicating no contact with land masses in the preceding 10 days. This was calculated using the Lagrangian Numerical Atmospheric-dispersion Modelling Environment (NAME) for the lower atmosphere (0$100 \mathrm{~m})$ as time-integrated particle density $\left(\mathrm{g} \mathrm{s} \mathrm{m}^{-3}\right)$, every $3 \mathrm{~h}$ from the ship location (Jones et al., 2007) as shown in Law et al. (2017). Where air contacted land masses, this was the New Zealand land mass in almost all cases.

$\mathrm{MeSH}_{\mathrm{a}}$ ranged from below detection limit $(<10 \mathrm{ppt})$ to $65 \mathrm{ppt}, \mathrm{DMS}_{\mathrm{a}}$ ranged from below detection limit $(\sim 22 \mathrm{ppt})$ up to $957 \mathrm{ppt}$, and acetone ${ }_{\mathrm{a}}$ ranged from 50 to $1500 \mathrm{ppt}$ (Table 2). The ratio of $\mathrm{MeSH}_{\mathrm{a}}$ to $\mathrm{DMS}_{\mathrm{a}}$ ranged from 0.03 to 0.36 (mean 0.14) for measurements when both were above the minimum detectable limit. Periods of elevated $\mathrm{DMS}_{\mathrm{a}}$ gen- 

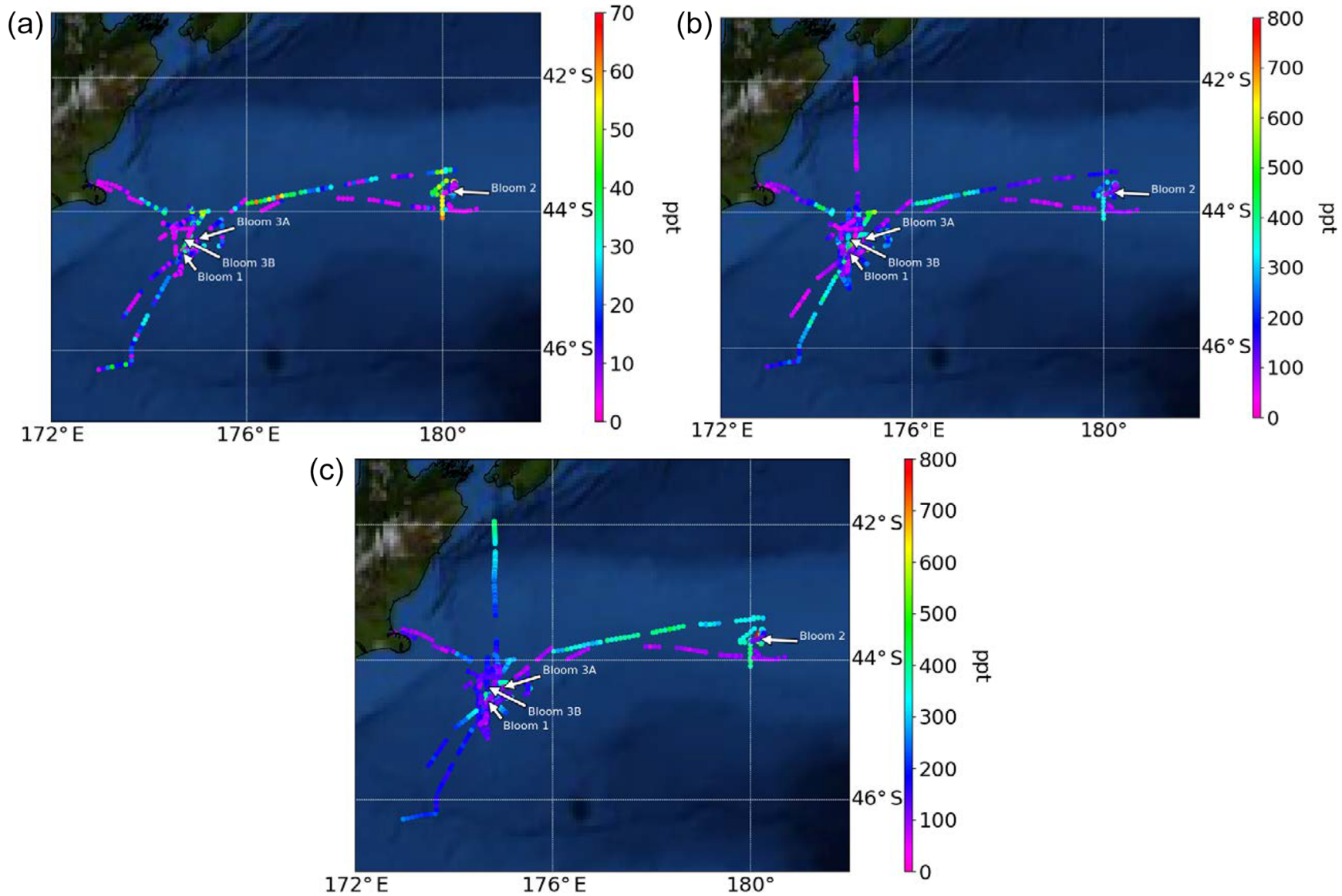

Figure 3. Atmospheric mixing ratios of (a) $\mathrm{MeSH}_{\mathrm{a}}$, (b) $\mathrm{DMS}_{\mathrm{a}}$ and (c) acetone $\mathrm{a}$ as a function of the voyage track. Location of the blooms are shown.

erally correspond to periods of elevated DMS $\mathrm{sw}_{\mathrm{sw}}$. Both $\mathrm{DMS}_{\mathrm{a}}$ and $\mathrm{DMS}_{\mathrm{sw}}$ were very high during $\mathrm{B} 1$, during the transect to $\mathrm{B} 2$, and the first half of $\mathrm{B} 2$ occupation. $\mathrm{MeSH}_{\mathrm{a}}$ variability broadly correlates with $\mathrm{DMS}_{\mathrm{a}}$ and $\mathrm{DMS}_{\mathrm{sw}}$, with highest levels during B2 (no data available for B1). The highest acetone $_{\mathrm{a}}$ levels observed occur during B2, and a broad acetone peak during B1 of $700 \mathrm{ppt}(\sim$ DOY 49$)$ overlaps with but is slightly offset from the largest $\mathrm{DMS}_{\mathrm{a}}$ peak during the voyage $(\sim 957 \mathrm{ppt})$. $\mathrm{DMS}_{\mathrm{a}}$, acetone $\mathrm{a}_{\mathrm{a}}$ and $\mathrm{MeSH}_{\mathrm{a}}$ were somewhat lower during $\mathrm{B} 3 \mathrm{a}$ and lowest during $\mathrm{B} 3 \mathrm{~b}$ (the poststorm part of that bloom B3) (see Law et al., 2017). In general, $\mathrm{DMS}_{\mathrm{a}}$ levels during $\mathrm{B} 1$ were at the upper range of those found in prior studies elsewhere (Lana et al., 2011; Law et al., 2017). $\mathrm{MeSH}_{\mathrm{a}}$ levels during $\mathrm{B} 2$ ranged from below detection limit ( $\sim 10 \mathrm{ppt}$ ) up to $65 \mathrm{ppt}$ (mean $25 \mathrm{ppt}$ ), which is substantially higher than the only comparable measurements from the Drake Passage and the coastal and inshore waters west of the Antarctic Peninsula (3.6 ppt) (Berresheim, 1987). The average acetone $e_{a}$ levels during this study were broadly comparable to those from similar latitudes reported in the South Atlantic and Southern Ocean (Williams et al., 2010) and at Cape Grim (Galbally et al., 2007). Acetone ${ }_{a}$ during SOAP was generally lower than at similar latitudes at Mace Head (Lewis et al., 2005), the southern Indian Ocean (Colomb et al., 2009) and also the marine subtopics (Read et al., 2012; Schlundt et al., 2017; Warneke and de Gouw, 2001; Williams et al., 2004).

There were two occasions when elevated acetone ${ }_{\mathrm{a}}$ corresponded closely to an increased land influence - during B1 on DOY 48-49 (maximum land influence $12 \%$ ) and DOY 60 (maximum land influence $20 \%$ ) (Fig. 4). Both these periods corresponded to winds from the north, and back trajectories show that the land mass contacted was the southern tip of New Zealand's North Island (including the city of Wellington and the northern section of the South Island in both cases). The acetone measured during these periods may have been emitted from anthropogenic and biogenic sources as well as from photochemical oxidation of hydrocarbon precursors (Fischer et al., 2012). The acetone enhancement relative to the degree of land influence was higher on DOY 48-49 than DOY 60 possibly due to different degrees of dilution of the terrestrial plume or different terrestrial source strengths.

The period with the highest acetone levels during B2 (1508 ppt) corresponds with a period of negligible land in- 

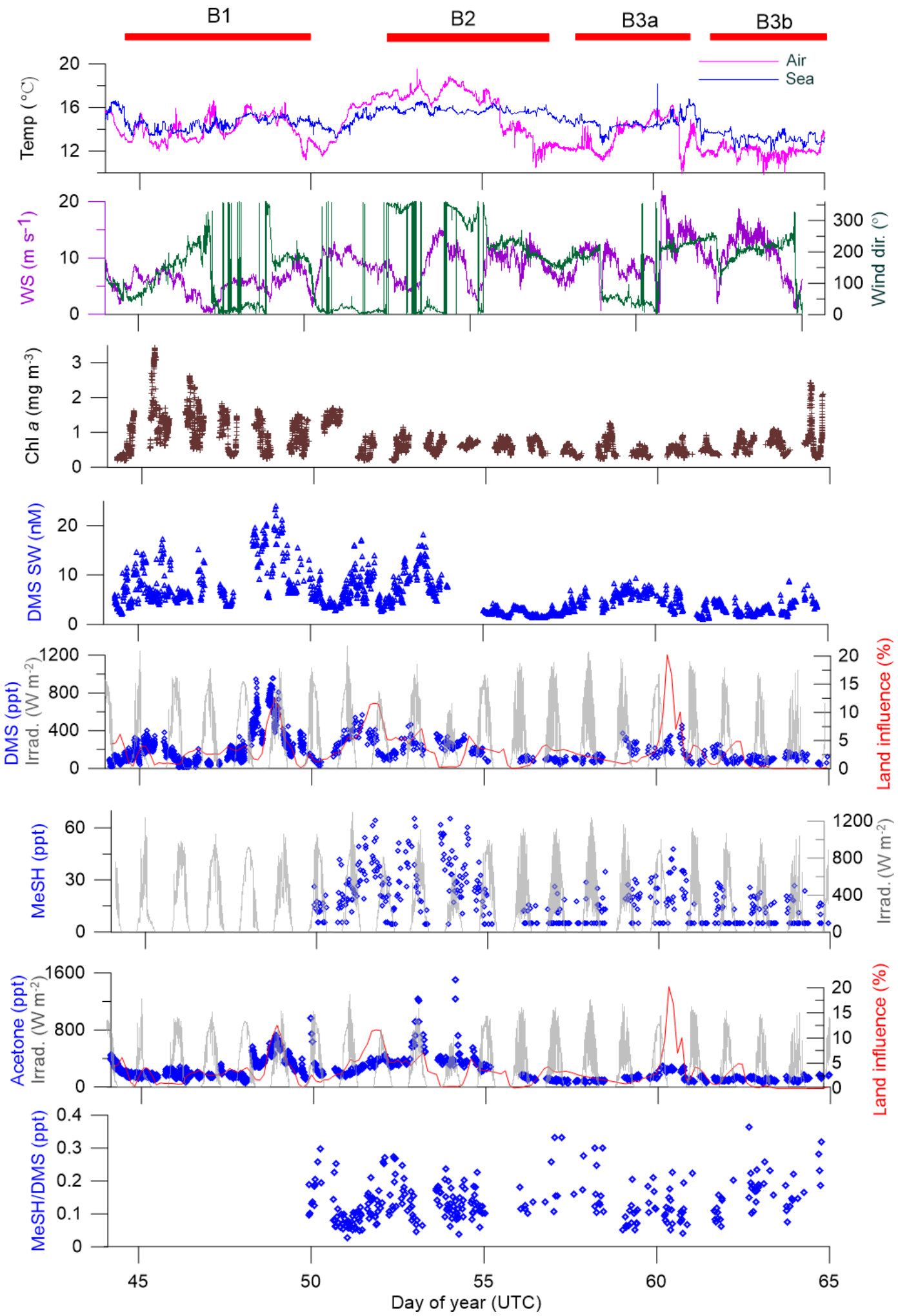

Figure 4. Time series of measurements during the SOAP voyage according to DOY. Atmospheric DMS and MeSH measurements below detection limit have had half detection limit substituted. WS represents wind speed, wind dir represents wind direction, Irrad. represents irradiance and Chl $a$ represents chlorophyll $a$. 
Table 3. Pearson correlations between $\mathrm{DMS}_{\mathrm{a}}, \mathrm{MeSH}_{\mathrm{a}}$ and acetone $_{\mathrm{a}}$, which are significant at the $95 \%$ confidence interval. Land-influenced data were removed (acetone).

\begin{tabular}{llrl}
\hline & & Slope $(p$ value $)$ & $R^{2}$ \\
\hline DMS vs. & All data $(n=266)$ & $0.07(<0.0001)$ & 0.3 \\
MeSH & B2 $(n=98)$ & $0.13(<0.0001)$ & 0.5 \\
& B3 $(n=76)$ & $0.03(0.001)$ & 0.1 \\
\hline DMS vs. & All data $(n=1301)$ & $0.30(<0.0001)$ & 0.1 \\
acetone & B1 $(n=883)$ & $0.19(<0.0001)$ & 0.1 \\
& B2 $(n=122)$ & $1.1(<0.0001)$ & 0.2 \\
\hline Acetone vs. & All data $(n=265)$ & $0.02(<0.0001)$ & 0.1 \\
MeSH & B3 $(n=76)$ & $0.06(0.03)$ & 0.1 \\
\hline
\end{tabular}

fluence $(0.3 \%)$, indicating a non-terrestrial, possibly local, source of acetone $\mathrm{a}_{\mathrm{a}}$. Neither $\mathrm{MeSH}_{\mathrm{a}}$ nor $\mathrm{DMS}_{\mathrm{a}}$ maxima corresponded with peaks in land influence, except for the latter part of the DMS $\mathrm{a}_{\mathrm{a}}$ maximum on DOY 48-49; however, the source of $\mathrm{DMS}_{\mathrm{a}}$ during DOY 48-49 is attributed to local ocean emissions as shown by strong association between $\mathrm{DMS}_{\mathrm{sw}}$ and $\mathrm{DMS}_{\mathrm{a}}$ during this period (Fig. 4).

Correlations of $\mathrm{DMS}_{\mathrm{a}}, \mathrm{MeSH}_{\mathrm{a}}$ and acetone $\mathrm{a}$ were examined to identify possible common marine sources or processes influencing atmospheric levels (Table 3). Only data above the minimum detectable limit were included in the regressions. Acetone ${ }_{a}$ data likely influenced by terrestrial sources (DOY 48-49 and 60, described above) were removed from this analysis. A moderate correlation $\left(R^{2}=0.5\right.$, $p<0.0001)$ was found between $\mathrm{DMS}_{\mathrm{a}}$ and $\mathrm{MeSH}_{\mathrm{a}}$ during B2 with a correlation of $R^{2}=0.3,(p<0.0001)$ between $\mathrm{DMS}_{\mathrm{a}}$ and $\mathrm{MeSH}_{\mathrm{a}}$ for all data (Fig. 5). During B2 the slope was $0.13\left(\mathrm{MeSH}_{\mathrm{a}}\right.$ roughly $13 \%$ of the $\mathrm{DMS}_{\mathrm{a}}$ mixing ratios), while for all data the slope was 0.07 (including blooms and transiting between blooms).

$\mathrm{MeSH}_{\mathrm{sw}}$ and $\mathrm{DMS}_{\mathrm{sw}}$ are produced from bacterial catabolism of DMSP via two competing processes, so the amount of $\mathrm{DMS}_{\mathrm{sw}}$ vs. $\mathrm{MeSH}_{\mathrm{sw}}$ produced from DMSP will depend on the relative importance of these two pathways at any given time. Additional sources of $\mathrm{DMS}_{\mathrm{sw}}$, such as phytoplankton that cleave DMSP into DMS, will also influence the amount of $\mathrm{DMS}_{\mathrm{sw}}$ vs. $\mathrm{MeSH}_{\mathrm{sw}}$ produced. A phytoplanktonmediated source of $\mathrm{DMS}_{\mathrm{sw}}$ was likely to be an important contributor to the $\mathrm{DMS}_{\mathrm{sw}}$ pool during the SOAP voyage, either through indirect processes (zooplankton grazing, viral lysis and senescence) or direct processes (algal DMSPlyase activity) (Lizotte et al., 2017). The relative loss rates of $\mathrm{DMS}_{\mathrm{sw}}$ and $\mathrm{MeSH}_{\mathrm{sw}}$ through oxidation, bacterial uptake or reaction with DOM will also influence the amount of each gas available to transfer to the atmosphere, with $\mathrm{MeSH}_{\text {sw }}$ having a much faster loss rate in seawater than $\mathrm{DMS}_{\mathrm{sw}}$ (Kiene and Linn, 2000; Kiene et al., 2000). Differences between the gas transfer velocities of DMS and MeSH would also affect the atmospheric mixing ratios. Such differences are likely to be small, due to similar solubilities (Sander, 2015) and diffusivities (Johnson, 2010). A final factor that will influence the slope of $\mathrm{DMS}_{\mathrm{a}}$ vs. $\mathrm{MeSH}_{\mathrm{a}}$ is the atmospheric lifetime (Table 2). The average lifetimes of $\mathrm{DMS}_{\mathrm{a}}$ and $\mathrm{MeSH}_{\mathrm{a}}$ in this study are estimated at 24 and $9 \mathrm{~h}$, respectively, with respect to $\mathrm{OH}$, calculated using DMS reaction rate of $\mathrm{OH}$ from Berresheim et al. (1987), the MeSH reaction rate from Atkinson et al. (1997) and OH concentration calculated as described in Lawson et al. (2015). Hence, the correlation between $\mathrm{DMS}_{\mathrm{a}}$ and $\mathrm{MeSH}_{\mathrm{a}}$ reflects the common seawater source of both gases, while the differing slopes between B2 and all data probably reflect the different sources and atmospheric lifetimes. While a correlation between $\mathrm{MeSH}$ and DMS has been observed in seawater samples previously (Kettle et al., 2001; Kiene et al., 2017), to our knowledge this is the first time that a correlation between $\mathrm{MeSH}_{\mathrm{a}}$ and $\mathrm{DMS}_{\mathrm{a}}$ has been observed in the atmosphere over the remote ocean.

There were several weak $\left(R^{2} \leq 0.2\right)$ but significant correlations between $\mathrm{DMS}_{\mathrm{a}}$ and acetone $\mathrm{a}_{\mathrm{a}}$ and acetone $\mathrm{a}_{\mathrm{a}}$ and $\mathrm{MeSH}_{\mathrm{a}}$ (Table 3). The correlation of acetone $\mathrm{a}_{\mathrm{a}}$ with $\mathrm{DMS}_{\mathrm{a}}$ may reflect elevated organic sources for photochemical production of acetone in regions of high dissolved sulfur species. A further discussion of drivers of $\mathrm{DMS}_{\mathrm{a}}$, acetone $\mathrm{a}$ and $\mathrm{MeSH}_{\mathrm{a}}$ mixing ratios is provided in Sect. 3.3.

An additional factor which may influence the measured mixing ratios of $\mathrm{DMS}_{\mathrm{a}}, \mathrm{MeSH}_{\mathrm{a}}$ and acetone $\mathrm{a}$ is entrainment of air from the free troposphere into the MBL. For shortlived DMS and MeSH (Table 2), free tropospheric air is most likely to be depleted in these gases compared to air sampled close to the ocean surface. Acetone is relatively long lived (Table 2) and has significant terrestrial sources (Fischer et al., 2012), and so, depending on the origin of the free tropospheric air, it could be enhanced or depleted relative to MBL air.

Figure 6 shows the voyage-average diurnal cycles for $\mathrm{DMS}_{\mathrm{a}}, \mathrm{MeSH}_{\mathrm{a}}$ and acetone $\mathrm{a}$. The diurnal cycle of $\mathrm{DMS}_{\mathrm{a}}$ shows variations by almost a factor of 3 from morning (maximum at 08:00, $330 \mathrm{ppt}$ ) to late afternoon (minimum, 16:00, $\sim 120 \mathrm{ppt}$. $\mathrm{A} \mathrm{DMS}_{\mathrm{a}}$ diurnal cycle with sunrise maximum and late afternoon minimum has been observed in many previous studies and is attributed to photochemical destruction by $\mathrm{OH}$. This includes Cape Grim baseline station, which samples air from the Southern Ocean (average minimum and maximum $\sim 40-70 \mathrm{ppt}$ ) (Ayers and Gillett, 2000), over the tropical Indian ocean (average minimum and maximum 25-60 ppt (Warneke and de Gouw, 2001) and at Kiritimati in the tropical Pacific (average minimum and maximum 120-200 ppt) (Bandy et al., 1996). The higher atmospheric levels in this study are due to high $\mathrm{DMS}_{\mathrm{sw}}$ concentrations ( $>15 \mathrm{nM}$ ). The amplitude of the DMS diurnal cycle is likely to have been influenced by stationing the vessel over blooms with high $\mathrm{DMS}_{\mathrm{sw}}$ from 08:00 each day and regional mapping of areas with lower $\mathrm{DMS}_{\mathrm{sw}}$ overnight (Law et al., 2017).

The diurnal cycle for $\mathrm{MeSH}_{\mathrm{a}}$ (Fig. 6b) shows similar behaviour to $\mathrm{DMS}_{\mathrm{a}}$ with the mixing ratios varying by a factor 

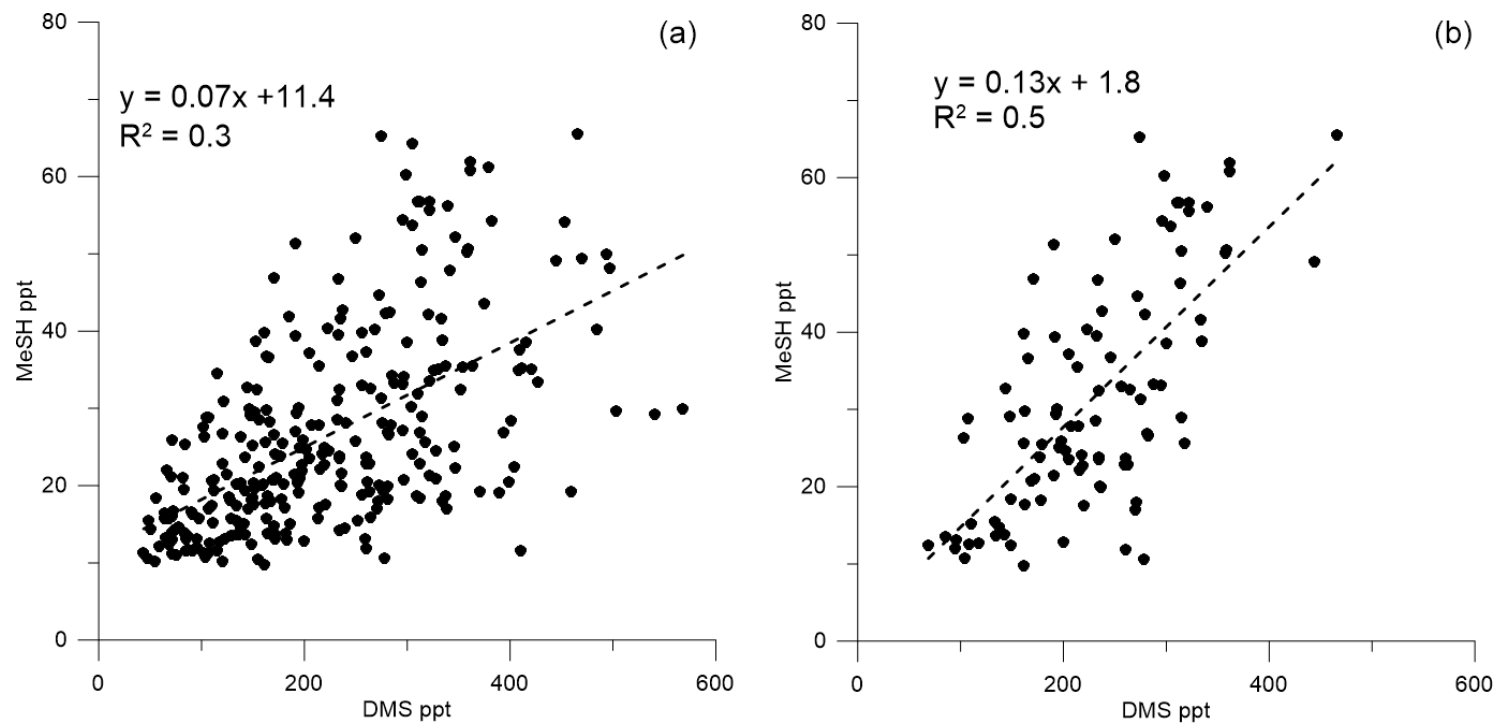

Figure 5. Correlation between (a) $\mathrm{DMS}_{\mathrm{a}}$ and $\mathrm{MeSH}_{\mathrm{a}}$ all data (DOY 49 onwards) and (b) $\mathrm{DMS}_{\mathrm{a}}$ and $\mathrm{MeSH}_{\mathrm{a}}$ bloom (B2) only.
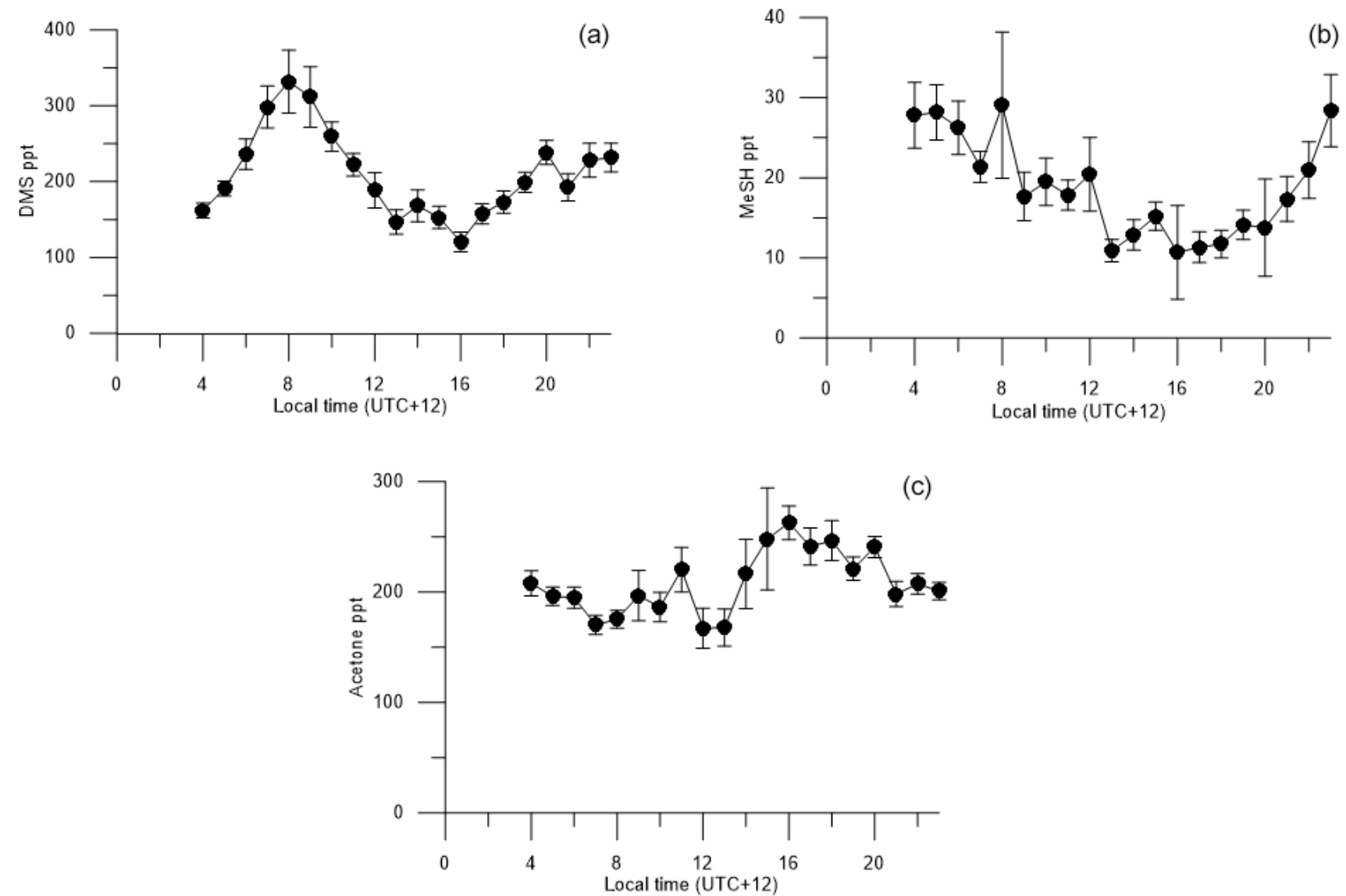

Figure 6. Diurnal cycles of (a) $\mathrm{DMS}_{\mathrm{a}}$, (b) $\mathrm{MeSH}_{\mathrm{a}}$, (c) acetone ${ }_{\mathrm{a}}$ with land-influenced data removed. Average values from 00:00 to 03:00 are excluded because of lower data collection during this period, due to calibrations and zero air measurements. 
Table 4. MeSH and DMS fluxes calculated using the nocturnal buildup method (NBM) compared with DMS flux measured using the eddy covariance (EC) method (Bell et al., 2015). The \pm values on the MeSH and DMS fluxes are due to the standard deviation (SD) of the MBL height.

\begin{tabular}{lcrrrrrr}
\hline Bloom & DOY & $\begin{array}{r}\text { MeSH } \\
\left(\mathrm{ppth}^{-1}\right)\end{array}$ & $\begin{array}{r}\text { DMS } \\
\left(\mathrm{ppth}^{-1}\right)\end{array}$ & $\begin{array}{r}\text { MeSH / MeSH } \\
+ \text { DMS }(\%)\end{array}$ & $\begin{array}{r}\text { Flux MeSH } \\
\left(\mu \mathrm{mol} \mathrm{m}^{-2} \mathrm{~d}^{-1}\right)\end{array}$ & $\begin{array}{r}\text { NBM flux DMS } \\
\left(\mu \mathrm{mol} \mathrm{m}^{-2} \mathrm{~d}^{-1}\right)\end{array}$ & $\begin{array}{r}\text { EC flux DMS } \\
\mathrm{mean}^{2} \mathrm{SD}\end{array}$ \\
\hline Just prior to B2 & $52.2-52.7$ & $3 \pm 1$ & $11 \pm 3$ & 24 & $3.5 \pm 2.0$ & $12.7 \pm 7.4$ & $7.6 \pm 4.8$ \\
B2 & $54.2-54.4$ & $5 \pm 1$ & $16 \pm 3$ & 23 & $5.8 \pm 3.4$ & $18.5 \pm 10.7$ & $26.4 \pm 9.7$ \\
B3a & $60.2-60.4$ & $4 \pm 2$ & $27 \pm 4$ & 14 & $4.8 \pm 2.8$ & $31.0 \pm 17.9$ & $29.4 \pm 8.2$ \\
\hline
\end{tabular}

of $\sim 2$ with the minimum mixing ratio occurring at around 16:00 (the same time as minimum $\mathrm{DMS}_{\mathrm{a}}$ ). The most important sink of $\mathrm{MeSH}_{\mathrm{a}}$ is thought to be oxidation by $\mathrm{OH}$ (Lee and Brimblecombe, 2016), and the minima in late afternoon may be due to destruction by $\mathrm{OH}$. The decoupling of the DMS and MeSH diurnal cycles between 04:00 and 08:00, with DMS increasing and MeSH decreasing, is likely due to the differing production pathways as well as the possibility of additional sinks for MeSH in the ocean during this time. This period may also have been influenced by mapping areas with lower $\mathrm{DMS}_{\mathrm{sw}}$ overnight and stationing the vessel over blooms with high $\mathrm{DMS}_{\mathrm{sw}}$ from 08:00 each day, as described above.

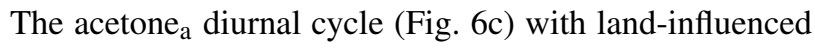
data removed shows reasonably consistent mixing ratios from the early morning until midday, with an overall increase in acetone levels during the afternoon hours from 14:00 onwards, then decreasing again at night, which is the opposite to the behaviour of $\mathrm{DMS}_{\mathrm{a}}$ and $\mathrm{MeSH}_{\mathrm{a}}$. Acetone is long lived $(\sim 60$ days - Table 2$)$ with respect to oxidation by $\mathrm{OH}$. The increase of acetone $\mathrm{a}_{\mathrm{a}}$ mixing ratios in the afternoon may indicate photochemical production from atmosphere or sea surface precursors but there was no correlation between irradiance and acetone $e_{\mathrm{a}}$ during the voyage.

\subsection{Flux calculation from nocturnal accumulation of MeSH}

MeSH and DMS fluxes $(F)$ were calculated according to the nocturnal accumulation method (Marandino et al., 2007). This approach assumes that nighttime photochemical losses are negligible and that sea surface emissions accumulate overnight within the well-mixed marine boundary layer (MBL). Horizontal homogeneity and zero flux at the top of the boundary layer are also assumed. The air-sea flux is calculated from the increase in MeSH and DMS. For example,

$F=\frac{\partial[\mathrm{MeSH}]}{\partial t} \times h$,

where $[\mathrm{MeSH}]$ is the concentration of $\mathrm{MeSH}\left(\mathrm{mol} \mathrm{m}^{-3}\right)$ and $h$ is the average nocturnal MBL for the voyage of $1135 \mathrm{~m} \pm 657 \mathrm{~m}$, estimated from nightly radiosonde flights.

DMS and MeSH fluxes were calculated for three nights (DOY 52, 54 and 60) (Table 4) when linear increases in mixing ratios occurred over several hours (Fig. 4). The MeSH flux was lowest on DOY 52 prior to B2 $\left(3.5 \pm 2 \mu \mathrm{mol}^{-1} \mathrm{~m}^{-2} \mathrm{~d}^{-1}\right)$, higher on DOY 60 during B3a $\left(4.8 \pm 2.8 \mu \mathrm{mol}^{-1} \mathrm{~m}^{-2} \mathrm{~d}^{-1}\right)$ and highest on DOY 42 during B2 $\left(5.8 \pm 3.4 \mu \mathrm{mol}^{-1} \mathrm{~m}^{-2} \mathrm{~d}^{-1}\right)$. There are no MeSH measurements during B1. The percentage of $\mathrm{MeSH} /(\mathrm{DMS}+\mathrm{MeSH})$ emitted varied from $14 \%$ for DOY 60 (B3a) up to $23 \%$ and $24 \%$ for DOY 54 (B2) and DOY 52 (prior to B2), respectively.

For comparison, the DMS fluxes measured using eddy covariance (EC) at the same time are given in Table 4 (Bell et al., 2015). DMS fluxes calculated using the nocturnal accumulation method are within the variability of the EC fluxes (Bell et al., 2015).

The average MeSH flux calculated from this study $\left(4.7 \mu \mathrm{mol} \mathrm{m}^{-2} \mathrm{~d}^{-1}\right)$ was more than 4 times higher than average MeSH fluxes from previous studies in the North Atlantic-South Atlantic transect (Kettle et al., 2001) and in the Baltic Sea, Kattegat, and North Sea (Leck and Rodhe, 1991) (Table 5). The MeSH fluxes calculated from this work are comparable to maximum values reported by Kettle et al. (2001), which were observed in localised coastal and upwelling regions. The average emission of MeSH compared to DMS (MeSH / (DMS + MeSH)) was higher in this study (20\%) compared to previous studies (Table 5) including the Baltic Sea, Kattegat, and North Sea (5\%, $4 \%$ and $11 \%)$; North Atlantic-South Atlantic (16\%); and a recent study from the northeast subarctic Pacific $(\sim 15 \%)$ (Kiene et al., 2017). Note that other sulfur species such as dimethyl disulfide (DMDS), carbon disulfide $\left(\mathrm{CS}_{2}\right)$ and hydrogen sulfide $\left(\mathrm{H}_{2} \mathrm{~S}\right)$ typically make a very small contribution to the total sulfur compared to DMS and MeSH (Leck and Rodhe, 1991; Kettle et al., 2001; Yvon et al., 1993), and so they are neglected from this calculation.

\subsection{Correlation with ocean biogeochemistry}

To investigate the influence of biogeochemical parameters on atmospheric mixing ratios of $\mathrm{MeSH}_{\mathrm{a}}, \mathrm{DMS}_{\mathrm{a}}$ and acetone $\mathrm{a}_{\mathrm{a}}$, Spearman rank correlations were undertaken to identify relationships significant at the $95 \%$ confidence interval (CI). Table 6 summarises the correlation coefficients and $p$ values for significant correlations. $\mathrm{MeSH}_{\mathrm{a}}, \mathrm{DMS}_{\mathrm{a}}$ and acetone $\mathrm{a}$ data 
Table 5. MeSH flux from this and previous studies (voyage averages).

\begin{tabular}{lrrl}
\hline Location & $\begin{array}{r}\text { MeSH flux } \\
\left(\mu \mathrm{mol} \mathrm{m}^{-2} \mathrm{~d}^{-1}\right)\end{array}$ & $\begin{array}{r}\text { Flux MeSH } / \\
\text { MeSH + DMS }(\%)\end{array}$ & Reference \\
\hline Baltic Sea & 0.2 & $5 \%$ & Leck and Rodhe (1991) \\
Kattegat sea & 0.8 & $4 \%$ & \\
North Sea & 1.6 & $11 \%$ & \\
\hline North Atlantic-South Atlantic & 1.2 & $16 \%$ & Kettle et al. (2001) \\
\hline Northeast subarctic Pacific & Not reported & $\sim 15 \%$ & Kiene et al. (2017) \\
\hline Southwest Pacific & 4.7 & $20 \%$ & This study \\
\hline
\end{tabular}

were averaged for $1 \mathrm{~h}$ either side of the CTD water entry time for the analysis.

Sulfur gases $\mathrm{MeSH}_{\mathrm{a}}$ and $\mathrm{DMS}_{\mathrm{a}}$ are short lived and so the air-sea flux is controlled by the seawater concentration. By contrast, acetone $\mathrm{a}_{\mathrm{a}}$ is much longer lived in the atmosphere ( $\sim 60$ days), so the air-sea gradient can be influenced by both oceanic emissions and atmospheric transport from other sources. As such, the variability in acetone ${ }_{a}$ mixing ratios may be driven by ocean-air exchange and/or input of acetone $_{\mathrm{a}}$ to the boundary layer from terrestrial sources, the upper atmosphere or in situ production. This means that correlation analyses to explore ocean biogeochemical sources of acetone $e_{a}$ may be confounded by atmospheric sources. Removal of land-influenced data reduces the likelihood of this, but observed increases in atmospheric acetone could still be from in situ processes such as oxidation of organic aerosol or mixing from above the boundary layer.

Both $\mathrm{MeSH}_{\mathrm{a}}$ and $\mathrm{DMS}_{\mathrm{a}}$ have a strong positive and highly significant relationship with $\mathrm{DMS}_{\mathrm{sw}}$, and a moderate correlation with discrete measurements of $\mathrm{DMSP}_{t}$ (total) and $\operatorname{DMSP}_{\mathrm{p}}$ (particulate). The correlation of $\mathrm{DMS}_{\mathrm{a}}$ with $\mathrm{DMS}_{\mathrm{sw}}$ can be attributed to the positive flux of DMS out of the ocean; however, the correlation of $\mathrm{MeSH}_{\mathrm{a}}$ with $\mathrm{DMS}_{\mathrm{sw}}$ is likely due to a common ocean precursor of both gases (DMSP), albeit via different production pathways. $\mathrm{DMS}_{\mathrm{a}}$ and $\mathrm{MeSH}_{\mathrm{a}}$ correlate with $\mathrm{DMSP}_{\mathrm{p}}$ (particulate) but not with $\mathrm{DMSP}_{\mathrm{d}}$ (dissolved). For $\mathrm{DMS}_{\mathrm{a}}$, the correlation may reflect that a proportion of the DMS observed was derived directly from phytoplankton rather than being bacterially mediated, which is in agreement with findings by Lizotte et al. (2017); however, as demethylation of $\mathrm{DMSP}_{\mathrm{d}}$ represents the primary source of $\mathrm{MeSH}$, the lack of correlation is surprising. The latter may reflect MeSH sinks in surface water associated with organics and particles (Kiene, 1996), and this could be confirmed via incubation experiments. DMS $_{\mathrm{a}}$ also correlated with particulate nitrogen and showed a moderate negative correlation with silicate that may reflect lower DMS production in diatom-dominated waters.

Acetone $_{a}$ shows a positive correlation with temperature and negative correlation with nutrients. This is consistent with reported sources of acetone $\mathrm{sw}_{\mathrm{w}}$ in warmer subtropical wa- ters (Beale et al., 2013; Yang et al., 2014a; Tanimoto et al., 2014; Schlundt et al., 2017). The positive relationship with organic material including HMW sugars and CDOM may reflect a photochemical ocean source (Zhou and Mopper, 1997; Dixon et al., 2013; de Bruyn et al., 2012; Kieber et al., 1990) or possibly a biological source (Nemecek-Marshall et al., 1995, 1999; Schlundt et al., 2017; Sinha et al., 2007; Halsey et al., 2017) as indicated by the correlations with cryptophyte and picoeukaryote abundance. Correlation with particle backscatter suggests potential links between acetone $\mathrm{a}_{\mathrm{a}}$ and coccolithophores (Sinha et al., 2007). Alternatively, the positive correlations of acetone $e_{a}$ with these organic components of sea water may reflect acetone production in the atmosphere from photochemical oxidation of ocean-derived organic aerosols (Pan et al., 2009; Kwan et al., 2006; Jacob et al., 2002). Seawater acetone measurements would allow for further elucidation of the relationships between acetone $_{\mathrm{a}}$ and biogeochemical parameters identified in this study. More generally, mesocosm or laboratory studies could be employed to identify the explicit sources and production mechanisms of these gases in Chatham Rise waters.

\section{Implications and conclusions}

Mixing ratios of short-lived $\mathrm{MeSH}_{\mathrm{a}}$ over the remote ocean of up to $65 \mathrm{ppt}$ in this study are the highest observed to date, and they provide evidence that MeSH transfers from the ocean into the atmosphere and may be present at non-negligible levels in the atmosphere over other regions of high biological productivity. The average MeSH flux calculated from this study $\left(4.7 \mu \mathrm{mol} \mathrm{m} \mathrm{m}^{-2} \mathrm{~d}^{-1}\right)$ was at least 4 times higher than average MeSH fluxes from previous studies, and it is comparable to maximum MeSH flux values reported in localised coastal and upwelling regions of the North Atlantic-South Atlantic (Kettle et al., 2001) (Table 5). The average emission of MeSH compared to DMS (MeSH / (DMS + MeSH)) was higher in this study (20\%) compared to previous studies $(4 \%-16 \%)$, indicating that MeSH provides a significant transfer of sulfur to the atmosphere in this region. Taken together with other studies, the magnitude of the ocean MeSH 
Table 6. Spearman rank correlations between acetone $\mathrm{a}_{\mathrm{a}}, \mathrm{DMS}_{\mathrm{a}}$ and $\mathrm{MeSH}_{\mathrm{a}}$, as well as biogeochemical parameters, using data from the 14 February-4 March 2012 (acetone ${ }_{\mathrm{a}}, \mathrm{DMS}_{\mathrm{a}}$ ) and 20 February-4 March $2012\left(\mathrm{MeSH}_{\mathrm{a}}\right)$. Correlations shown are significant at the $95 \%$ confidence interval (CI). Correlation coefficient (and $p$ value) are shown. No entry indicates there was no correlation at $95 \%$ CI. Landinfluenced acetone $_{\mathrm{a}}$ data excluded (see text for details).

\begin{tabular}{|c|c|c|c|}
\hline & Acetone $_{\mathrm{a}}$ & $\mathrm{DMS}_{\mathrm{a}}$ & $\mathrm{MeSH}_{\mathrm{a}}$ \\
\hline \multicolumn{4}{|l|}{ Positive correlations } \\
\hline Salinity (psu) & $\begin{array}{l}0.55(0.005) \\
n=25\end{array}$ & & \\
\hline Sea temperature $\left({ }^{\circ} \mathrm{C}\right)$ & $\begin{array}{l}0.77(<0.0001) \\
n=25\end{array}$ & & \\
\hline beta- 660 backscatter $\left(\mathrm{m}^{-2} \mathrm{sr}^{-1}\right)$ & $\begin{array}{l}0.67(0.0004) \\
n=25\end{array}$ & & \\
\hline $\mathrm{DMS}_{\mathrm{SW}}(\mathrm{nM})$ & $\begin{array}{l}0.49(0.025) \\
n=21\end{array}$ & $\begin{array}{l}0.73(0.0002) \\
n=22\end{array}$ & $\begin{array}{l}0.59(0.011) \\
n=18\end{array}$ \\
\hline Chl $a /$ mixed layer depth & $\begin{array}{l}0.50(0.014) \\
n=25\end{array}$ & & \\
\hline Particulate nitrogen $\left(\mathrm{mg} \mathrm{m}^{-3}\right)$ & & $\begin{array}{l}0.79(0.048) \\
n=7\end{array}$ & \\
\hline Cryptophyte algae (cells $\mathrm{mL}^{-1}$ ) & $\begin{array}{l}0.47(0.019) \\
n=25\end{array}$ & & \\
\hline Eukaryotic picoplankton (cells $\mathrm{mL}^{-1}$ ) & $\begin{array}{l}0.48(0.016) \\
n=25\end{array}$ & & \\
\hline $\operatorname{DMSP}_{\mathrm{t}}\left(\mathrm{nmol} \mathrm{L}^{-1}\right)$ & & $\begin{array}{l}0.54(0.011) \\
n=22\end{array}$ & $\begin{array}{l}0.59(0.014) \\
n=17\end{array}$ \\
\hline $\operatorname{DMSP}_{\mathrm{p}}\left(\mathrm{nmol} \mathrm{L}^{-1}\right)$ & & $\begin{array}{l}0.56(0.007) \\
n=22\end{array}$ & $\begin{array}{l}0.53(0.032) \\
n=17\end{array}$ \\
\hline CDOM (ppb) & $\begin{array}{l}0.48(0.041) \\
n=20\end{array}$ & & \\
\hline HMW reducing sugars $\left(\mu g \mathrm{~L}^{-1}\right)$ & $\begin{array}{l}0.67(0.011) \\
n=14\end{array}$ & & \\
\hline Negative correlations & & & \\
\hline Chl $a$ /backscatter 660 & $\begin{array}{l}-0.47(0.019) \\
n=25\end{array}$ & & \\
\hline Mixed layer depth (m) & $\begin{array}{l}-0.66(0.0005) \\
n=25\end{array}$ & & \\
\hline Dissolved oxygen $\left(\mu \mathrm{mol} \mathrm{kg}{ }^{-1}\right)$ & $\begin{array}{l}-0.45(0.030) \\
n=24\end{array}$ & & \\
\hline Phosphate $\left(\mu \mathrm{mol} \mathrm{L}{ }^{-1}\right)$ & $\begin{array}{l}-0.54(0.006) \\
n=25\end{array}$ & & \\
\hline Nitrate $\left(\mu \mathrm{mol} \mathrm{L}{ }^{-1}\right)$ & $\begin{array}{l}-0.60(0.002) \\
n=25\end{array}$ & & \\
\hline Silicate $\left(\mu \mathrm{mol} \mathrm{L}{ }^{-1}\right)$ & $\begin{array}{l}-0.50(0.012) \\
n=25\end{array}$ & $\begin{array}{l}-0.43(0.031) \\
n=26\end{array}$ & \\
\hline Monounsaturated fatty acids $\left(\mu \mathrm{g} \mathrm{L}{ }^{-1}\right)$ & $\begin{array}{l}-0.82(0.007) \\
n=10\end{array}$ & & \\
\hline
\end{tabular}

flux to the atmosphere appears to be highly variable as is the proportion of S emitted as MeSH compared to DMS. For example, MeSH fluxes in the Kettle et al. (2001) study varied by several orders of magnitude, and in some cases the MeSH flux equalled the DMS flux. Similarly, $\mathrm{DMS}_{\mathrm{sw}} / \mathrm{MeSH}_{\mathrm{sw}}$ concentration ratios have varied substantially (Kettle et al., 2001, Leck and Rodhe, 1991; Kiene et al., 2017). As such, further studies are needed to investigate the spatial distribution of MeSH both in seawater and the atmosphere as well as the importance of MeSH as a source of atmospheric sulfur. The fate of atmospheric MeSH sulfur in the atmosphere is also highly uncertain, in terms of its degradation pathways, reactions, and intermediate and final degradation products. For example, the impact that oxidation of $\mathrm{MeSH}_{\mathrm{a}}$ has on the 
oxidative capacity of the MBL, and on other processes such as particle formation or growth, to the best of our knowledge remains largely unknown, and further work is needed on its atmospheric processes and fate.

A correlation analysis of $\mathrm{MeSH}_{\mathrm{a}}$ and biogeochemical parameters was undertaken for the first time, and it showed that $\mathrm{MeSH}_{\mathrm{a}}$, as well as $\mathrm{DMS}_{\mathrm{a}}$, correlated with their ocean precursor, DMSP, and also correlated with seawater DMS $\left(\mathrm{DMS}_{\mathrm{sw}}\right)$. The correlation of $\mathrm{MeSH}_{\mathrm{a}}$ with $\mathrm{DMS}_{\mathrm{sw}}$ is likely due to a common ocean precursor of both gases (DMSP), which is produced via different pathways.

Correlation of acetone $\mathrm{a}_{\mathrm{a}}$ with biogeochemical parameters suggests a source of acetone from warmer subtropical ocean waters, in line with other studies, with positive correlations between acetone $_{\mathrm{a}}$ and ocean temperature, high-molecularweight sugars, cryptophyte, eukaryote phytoplankton, chromophoric dissolved organic matter (CDOM), and particle backscatter, and a negative correlation with nutrients. While data with a terrestrial source influence were removed from this analysis, it is still possible that the acetone peaks observed may not have been due to a positive flux of acetone from the ocean but rather from in situ processes, leading to acetone production such as oxidation of marine-derived organic aerosol.

Finally, the SOAP voyage provided the opportunity to compare three independently calibrated $\mathrm{DMS}_{\mathrm{a}}$ measurement techniques at sea (PTR-MS, mesoCIMS and GC-SCD). Agreement between the three techniques was generally good; however, some systematic differences between the datasets were observed. Some of these differences were attributed to the near-surface DMS gradient and the use of different inlet heights (28 and $12 \mathrm{~m}$ a.s.l. for the PTR-MS and mesoCIMS, respectively), as well as differing approaches of integrated versus discrete measurements. The remaining discrepancies are likely due to differences in calibration scales, suggesting that further investigation of the stability and/or absolute calibration of DMS standards used at sea is warranted.

Data availability. DMS, acetone and MeSH data are available via the CSIRO data access portal (DAP) at https://doi.org/10.25919/5d914b00c5759 (Lawson, 2019). Further data are available by emailing the corresponding author or the voyage leader: cliff.law@niwa.co.nz.

Supplement. The supplement related to this article is available online at: https://doi.org/10.5194/acp-20-3061-2020-supplement.

Author contributions. SJL wrote the paper. CSL led the research voyage. All authors operated instrumentation during the voyage and contributed data. All authors contributed to data analysis and/or interpretation.
Competing interests. The authors declare that they have no conflict of interest.

Special issue statement. This article is part of the special issue "Surface Ocean Aerosol Production (SOAP) (ACP/OS inter-journal SI)". It is not associated with a conference.

Acknowledgements. We thank the officers and crew of the RV Tangaroa and NIWA vessels for logistics support. Many thanks to John McGregor (NIWA) for providing land influence data and to Paul Selleck and Erin Dunne (CSIRO) for helpful discussions. Thanks to the NIWA Visiting Scientist Scheme and CSIRO's Capability Development Fund for providing financial support for Sarah Lawson's participation in the SOAP voyage.

Review statement. This paper was edited by Mario Hoppema and reviewed by Cathleen Schlundt and one anonymous referee.

\section{References}

Alcolombri, U., Ben-Dor, S., Feldmesser, E., Levin, Y., Tawfik, D. S., and Vardi, A.: Identification of the algal dimethyl sulfidereleasing enzyme: A missing link in the marine sulfur cycle, Science, 348, 1466-1469, https://doi.org/10.1126/science.aab1586, 2015.

Atkinson, R.: Kinetics and mechanisms of the gas-phase reactions of the hydroxyl radical with organic compounds under atmospheric conditions, Chem. Rev., 86, 69-201, https://doi.org/10.1021/cr00071a004, 1986.

Atkinson, R., Baulch, D. L., Cox, R. A., Hampson, R. F., Kerr, J. A., Rossi, M. J., and Troe, J.: Evaluated Kinetic, Photochemical and Heterogeneous Data for Atmospheric Chemistry: Supplement V. - IUPAC Subcommittee on Gas Kinetic Data Evaluation for Atmospheric Chemistry, J. Phys. Chem. Ref. Data, 26, 521-1011, https://doi.org/10.1063/1.556011, 1997.

Ayers, G. P. and Gillett, R. W.: DMS and its oxidation products in the remote marine atmosphere: implications for climate and atmospheric chemistry, J. Sea Res., 43, 275-286, 2000.

Bandy, A. R., Thornton, D. C., Blomquist, B. W., Chen, S., Wade, T. P., Ianni, J. C., Mitchell, G. M., and Nadler, W.: Chemistry of dimethyl sulfide in the equatorial Pacific atmosphere, Geophys. Res. Lett., 23, 741-744, https://doi.org/10.1029/96g100779, 1996.

Beale, R., Dixon, J. L., Arnold, S. R., Liss, P. S., and Nightingale, P. D.: Methanol, acetaldehyde, and acetone in the surface waters of the Atlantic Ocean, J. Geophys. Res.-Oceans, 118, 5412-5425, https://doi.org/10.1002/jgrc.20322, 2013.

Beale, R., Dixon, J. L., Smyth, T. J., and Nightingale, P. D.: Annual study of oxygenated volatile organic compounds in UK shelf waters, Mar. Chem., 171, 96-106, https://doi.org/10.1016/j.marchem.2015.02.013, 2015.

Bell, T. G., De Bruyn, W., Miller, S. D., Ward, B., Christensen, K. H., and Saltzman, E. S.: Air-sea dimethylsulfide (DMS) gas transfer in the North Atlantic: evidence for limited interfacial gas 
exchange at high wind speed, Atmos. Chem. Phys., 13, 1107311087, https://doi.org/10.5194/acp-13-11073-2013, 2013.

Bell, T. G., De Bruyn, W., Marandino, C. A., Miller, S. D., Law, C. S., Smith, M. J., and Saltzman, E. S.: Dimethylsulfide gas transfer coefficients from algal blooms in the Southern Ocean, Atmos. Chem. Phys., 15, 1783-1794, https://doi.org/10.5194/acp15-1783-2015, 2015.

Berresheim, H.: Biogenic sulfur emissions from the Subantarctic and Antarctic Oceans, J. Geophys. Res., 92, 13245-13262, https://doi.org/10.1029/JD092iD11p13245, 1987.

Burrell, T. J.: Bacterial extracellular enzyme activity in a future ocean, $\mathrm{PhD}$ thesis, Victoria University of Wellington, $324 \mathrm{pp}$., 2015.

Carpenter, L. J., Archer, S. D., and Beale, R.: Ocean-atmosphere trace gas exchange, Chem. Soc. Rev., 41, 6473-6506, https://doi.org/10.1039/c2cs35121h, 2012.

Carpenter, L. J. and Nightingale, P. D.: Chemistry and Release of Gases from the Surface Ocean, Chem. Rev., 115, 4015-4034, https://doi.org/10.1021/cr5007123, 2015.

Charlson, R., Lovelock, J., Andreae, M., and Warren, S.: Oceanic phytoplankton, atmospheric sulphur, cloud albedo and climate, Nature, 326, 655-661, https://doi.org/10.1038/326655a0, 1987.

Colomb, A., Gros, V., Alvain, S., Sarda-Esteve, R., Bonsang, B., Moulin, C., Klupfel, T., and Williams, J.: Variation of atmospheric volatile organic compounds over the Southern Indian Ocean (30-49 ${ }^{\circ}$ S), Environ. Chem., 6, 70-82, https://doi.org/10.1071/en08072, 2009.

de Bruyn, W. J., Clark, C. D., Pagel, L., and Takehara, C.: Photochemical production of formaldehyde, acetaldehyde and acetone from chromophoric dissolved organic matter in coastal waters, J. Photoch. Photobio. A, 226, 16-22, https://doi.org/10.1016/j.jphotochem.2011.10.002, 2012.

Dixon, J. L., Beale, R., and Nightingale, P. D.: Production of methanol, acetaldehyde, and acetone in the Atlantic Ocean, Geophys. Res. Lett., 40, 4700-4705, https://doi.org/10.1002/grl.50922, 2013.

Feilberg, A., Liu, D., Adamsen, A. P. S., Hansen, M. J., and Jonassen, K. E. N.: Odorant Emissions from Intensive Pig Production Measured by Online Proton-Transfer-Reaction Mass Spectrometry, Environ. Sci. Technol., 44, 5894-5900, https://doi.org/10.1021/es100483s, 2010.

Fischer, E. V., Jacob, D. J., Millet, D. B., Yantosca, R. M., and Mao, J.: The role of the ocean in the global atmospheric budget of acetone, Geophys. Res. Lett., 39, L01807, https://doi.org/10.1029/2011g1050086, 2012.

Flöck, O. R. and Andreae, M. O.: Photochemical and nonphotochemical formation and destruction of carbonyl sulfide and methyl mercaptan in ocean waters, Mar. Chem., 54, 11-26, https://doi.org/10.1016/0304-4203(96)00027-8, 1996.

Galbally, I. E., Lawson, S. J., Weeks, I. A., Bentley, S. T., Gillett, R. W., Meyer, M., and Goldstein, A. H.: Volatile organic compounds in marine air at Cape Grim, Australia, Environ. Chem., 4, 178182, https://doi.org/10.1071/en07024, 2007.

Gall, M. P., Davies-Colley, R. J., and Merrilees, R. A.: Exceptional visual clarity and optical purity in a sub-alpine lake, Limnol. Oceanogr., 58, 443-451, https://doi.org/10.4319/lo.2013.58.2.0443, 2013.

Hall, J. A. and Safi, K.: The impact of in situ Fe fertilisation on the microbial food web in the Southern Ocean, Deep-Sea Res. Pt II,
48, 2591-2613, https://doi.org/10.1016/S0967-0645(01)000108, 2001.

Halsey, K. H., Giovannoni, S. J., Graus, M., Zhao, Y., Landry, Z., Thrash, J. C., Vergin, K. L., and de Gouw, J.: Biological cycling of volatile organic carbon by phytoplankton and bacterioplankton, Limnol. Oceanogr., 62, 2650-2661, https://doi.org/10.1002/lno.10596, 2017.

ISO: ISO 6879: Air Quality, Performance Characteristics and Related Concepts for Air Quality Measuring Methods, International Organisation for Standardisation, Geneva, Switzerland, 1995.

Jacob, D. J., Field, B. D., Jin, E. M., Bey, I., Li, Q. B., Logan, J. A., Yantosca, R. M., and Singh, H. B.: Atmospheric budget of acetone, J. Geophys. Res.-Atmos., 107, 4100, https://doi.org/10.1029/2001jd000694, 2002.

Johnson, M. T.: A numerical scheme to calculate temperature and salinity dependent air-water transfer velocities for any gas, Ocean Sci., 6, 913-932, https://doi.org/10.5194/os-6-913-2010, 2010.

Jones, A. R., Thomson, D. J., Hort, M., and Devenish, B.: The UK Met Office's next-generation atmospheric dispersion model, NAME III, in: Proceedings of the 27th NATO/CCMS International Technical Meeting on Air Pollution Modelling and its Application, edited by: Borrego, C. and Norman, A.-L., Springer, 580-589, 2007.

Kettle, A. J., Rhee, T. S., von Hobe, M., Poulton, A., Aiken, J., and Andreae, M. O.: Assessing the flux of different volatile sulfur gases from the ocean to the atmosphere, J. Geophys. Res., 106, 12193-12209, https://doi.org/10.1029/2000jd900630, 2001.

Kieber, R. J., Zhou, X., and Mopper, K.: Formation of carbonyl compounds from UV-induced photodegradation of humic substances in natural waters: Fate of riverine carbon in the sea, Limnol. Oceanogr., 35, 1503-1515, https://doi.org/10.4319/lo.1990.35.7.1503, 1990.

Kiene, R. P.: Production of methanethiol from dimethylsulfoniopropionate in marine surface waters, Mar. Chem., 54, 69-83, https://doi.org/10.1016/0304-4203(96)00006-0, 1996.

Kiene, R. P. and Linn, L. J.: The fate of dissolved dimethylsulfoniopropionate (DMSP) in seawater: tracer studies using ${ }^{35}$ S-DMSP, Geochim. Cosmochim. Ac., 64, 2797-2810, https://doi.org/10.1016/S0016-7037(00)00399-9, 2000.

Kiene, R. P., Linn, L. J., and Bruton, J. A.: New and important roles for DMSP in marine microbial communities, J. Sea Res., 43, 209-224, https://doi.org/10.1016/S1385-1101(00)00023-X, 2000.

Kiene, R. P., Williams, T. E., Esson, K., Tortell, P. D., and Dacey, J. W. H.: Methanethiol Concentrations and Sea-Air Fluxes in the Subarctic NE Pacific Ocean, American Geophysical Union, Fall meeting, 2017.

Kwan, A. J., Crounse, J. D., Clarke, A. D., Shinozuka, Y., Anderson, B. E., Crawford, J. H., Avery, M. A., McNaughton, C. S., Brune, W. H., Singh, H. B., and Wennberg, P. O.: On the flux of oxygenated volatile organic compounds from organic aerosol oxidation, Geophys. Res. Lett., 33, L15815, https://doi.org/10.1029/2006g1026144, 2006.

Lana, A., Bell, T. G., Simó, R., Vallina, S. M., Ballabrera-Poy, J., Kettle, A. J., Dachs, J., Bopp, L., Saltzman, E. S., Stefels, J., Johnson, J. E., and Liss, P. S.: An updated climatology of surface dimethlysulfide concentrations and emission fluxes in the global ocean, Global Biogeochem. Cy., 25, GB1004, https://doi.org/10.1029/2010gb003850, 2011. 
Law, C. S., Brévière, E., de Leeuw, G., Garçon, V., Guieu, C., Kieber, D. J., Kontradowitz, S., Paulmier, A., Quinn, P. K., Saltzman, E. S., Stefels, J., and von Glasow, R.: Evolving research directions in Surface Ocean-Lower Atmosphere (SOLAS) science, Environ. Chem., 10, 1-16, https://doi.org/10.1071/EN12159, 2013.

Law, C. S., Smith, M. J., Harvey, M. J., Bell, T. G., Cravigan, L. T., Elliott, F. C., Lawson, S. J., Lizotte, M., Marriner, A., McGregor, J., Ristovski, Z., Safi, K. A., Saltzman, E. S., Vaattovaara, P., and Walker, C. F.: Overview and preliminary results of the Surface Ocean Aerosol Production (SOAP) campaign, Atmos. Chem. Phys., 17, 13645-13667, https://doi.org/10.5194/acp-1713645-2017, 2017

Law, C. S., Woodward, E. M. S., Ellwood, M. J., Marriner, A., Bury, S. J., and Safi, K. A.: Response of surface nutrient inventories and nitrogen fixation to a tropical cyclone in the southwest Pacific, Limnol. Oceanogr., 56, 1372-1385, https://doi.org/10.4319/lo.2011.56.4.1372, 2011.

Lawson, S.: DMS, acetone, methanethiol atmospheric data from SOAP voyage. v1. CSIRO, Data Collection, https://doi.org/10.25919/5d914b00c5759, 2019.

Lawson, S. J., Selleck, P. W., Galbally, I. E., Keywood, M. D., Harvey, M. J., Lerot, C., Helmig, D., and Ristovski, Z.: Seasonal in situ observations of glyoxal and methylglyoxal over the temperate oceans of the Southern Hemisphere, Atmos. Chem. Phys., 15, 223-240, https://doi.org/10.5194/acp-15-223-2015, 2015.

Leck, C. and Rodhe, H..: Emissions of marine biogenic sulfur to the atmosphere of northern Europe, J. Atmos. Chem., 12, 63-86, https://doi.org/10.1007/bf00053934, 1991.

Lee, C. L. and Brimblecombe, P.: Anthropogenic contributions to global carbonyl sulfide, carbon disulfide and organosulfides fluxes, Earth-Sci. Rev., 160, 1-18, https://doi.org/10.1016/j.earscirev.2016.06.005, 2016.

Lewis, A. C., Hopkins, J. R., Carpenter, L. J., Stanton, J., Read, K. A., and Pilling, M. J.: Sources and sinks of acetone, methanol, and acetaldehyde in North Atlantic marine air, Atmos. Chem. Phys., 5, 1963-1974, https://doi.org/10.5194/acp-5-1963-2005, 2005.

Liss, P. S. and Johnson, M. T. (Eds.): Ocean-Atmosphere Interactions of Gases and Particles, Springer Earth System Sciences, 315 pp., 2014.

Lizotte, M., Levasseur, M., Law, C. S., Walker, C. F., Safi, K. A., Marriner, A., and Kiene, R. P.: Dimethylsulfoniopropionate (DMSP) and dimethyl sulfide (DMS) cycling across contrasting biological hotspots of the New Zealand subtropical front, Ocean Sci., 13, 961-982, https://doi.org/10.5194/os-13961-2017, 2017.

Malin, G.: Sulphur, climate and the microbial maze, Nature, 387, 857-858, https://doi.org/10.1038/43075, 1997.

Marandino, C. A., De Bruyn, W. J., Miller, S. D., Prather, M. J., and Saltzman, E. S.: Oceanic uptake and the global atmospheric acetone budget, Geophys. Res. Lett., 32, L15806, https://doi.org/10.1029/2005g1023285, 2005.

Marandino, C. A., De Bruyn, W. J., Miller, S. D., and Saltzman, E. S.: Eddy correlation measurements of the air/sea flux of dimethylsulfide over the North Pacific Ocean, J. Geophys. Res.Atmos., 112, D03301, https://doi.org/10.1029/2006jd007293, 2007.
Nemecek-Marshall, M., Wojciechowski, C., Kuzma, J., Silver, G. M., and Fall, R.: Marine Vibrio species produce the volatile organic compound acetone, Appl. Environ. Microbiol., 61, 44-47, 1995.

Nemecek-Marshall, M., Wojciechowski, C., Wagner, W. P., and Fall, R.: Acetone formation in the Vibrio family: a new pathway for bacterial leucine catabolism, J. Bacteriol., 181, 7493-7499, 1999.

Nodder, S. D., Chiswell, S. M., and Northcote, L. C.: Annual cycles of deep-ocean biogeochemical export fluxes in subtropical and subantarctic waters, southwest Pacific Ocean, J. Geophys. Res.Oceans, 121, 2405-2424, https://doi.org/10.1002/2015jc011243, 2016.

Pan, X., Underwood, J. S., Xing, J.-H., Mang, S. A., and Nizkorodov, S. A.: Photodegradation of secondary organic aerosol generated from limonene oxidation by ozone studied with chemical ionization mass spectrometry, Atmos. Chem. Phys., 9, 38513865, https://doi.org/10.5194/acp-9-3851-2009, 2009.

Quinn, P. K. and Bates, T. S.: The case against climate regulation via oceanic phytoplankton sulphur emissions, Nature, 480, 5156, https://doi.org/10.1038/nature10580, 2011.

Read, K. A., Carpenter, L. J., Arnold, S. R., Beale, R., Nightingale, P. D., Hopkins, J. R., Lewis, A. C., Lee, J. D., Mendes, L., and Pickering, S. J.: Multiannual Observations of Acetone, Methanol, and Acetaldehyde in Remote Tropical Atlantic Air: Implications for Atmospheric OVOC Budgets and Oxidative Capacity, Environ. Sci. Technol., 46, 11028-11039, https://doi.org/10.1021/es302082p, 2012.

Safi, K. A., Griffiths, F. B., and Hall, J. A.: Microzooplankton composition, biomass and grazing rates along the WOCE SR3 line between Tasmania and Antarctica, Deep-Sea Res. Pt I, 54, 1025 1041, https://doi.org/10.1016/j.dsr.2007.05.003, 2007.

Sander, R.: Compilation of Henry's law constants (version 4.0) for water as solvent, Atmos. Chem. Phys., 15, 4399-4981, https://doi.org/10.5194/acp-15-4399-2015, 2015.

Schlundt, C., Tegtmeier, S., Lennartz, S. T., Bracher, A., Cheah, W., Krüger, K., Quack, B., and Marandino, C. A.: Oxygenated volatile organic carbon in the western Pacific convective center: ocean cycling, air-sea gas exchange and atmospheric transport, Atmos. Chem. Phys., 17, 10837-10854, https://doi.org/10.5194/acp-17-10837-2017, 2017.

Simó, R. and Pedrós-Alió, C.: Short-term variability in the open ocean cycle of dimethylsulfide, Glocal Biogeochem. Cy., 13, 1173-1181, https://doi.org/10.1029/1999gb900081, 1999.

Sinha, V., Williams, J., Meyerhöfer, M., Riebesell, U., Paulino, A. I., and Larsen, A.: Air-sea fluxes of methanol, acetone, acetaldehyde, isoprene and DMS from a Norwegian fjord following a phytoplankton bloom in a mesocosm experiment, Atmos. Chem. Phys., 7, 739-755, https://doi.org/10.5194/acp-7739-2007, 2007.

Smith, M. J., Walker, C. F., Bell, T. G., Harvey, M. J., Saltzman, E. S., and Law, C. S.: Gradient flux measurements of seaair DMS transfer during the Surface Ocean Aerosol Production (SOAP) experiment, Atmos. Chem. Phys., 18, 5861-5877, https://doi.org/10.5194/acp-18-5861-2018, 2018.

Somogyi, M.: Notes on Sugar Determination, J. Biol. Chem., 70, 599-612, 1926.

Somogyi, M.: Notes on Sugar Determination, J. Biol. Chem., 195, 19-23, 1952. 
Sun, J., Todd, J. D., Thrash, J. C., Qian, Y., Qian, M. C., Temperton, B., Guo, J., Fowler, E. K., Aldrich, J. T., Nicora, C. D., Lipton, M. S., Smith, R. D., De Leenheer, P., Payne, S. H., Johnston, A. W. B., Davie-Martin, C. L., Halsey, K. H., and Giovannoni, S. J.: The abundant marine bacterium Pelagibacter simultaneously catabolizes dimethylsulfoniopropionate to the gases dimethyl sulfide and methanethiol, Nat. Microbiol., 1, 16065, https://doi.org/10.1038/nmicrobiol.2016.65, 2016.

Taddei, S., Toscano, P., Gioli, B., Matese, A., Miglietta, F., Vaccari, F. P., Zaldei, A., Custer, T., and Williams, J.: Carbon Dioxide and Acetone Air-Sea Fluxes over the Southern Atlantic, Environ. Sci. Technol., 43, 5218-5222, https://doi.org/10.1021/es8032617, 2009.

Tanimoto, H., Kameyama, S., Iwata, T., Inomata, S., and Omori, Y.: Measurement of Air-Sea Exchange of Dimethyl Sulfide and Acetone by PTR-MS Coupled with Gradient Flux Technique, Environ. Sci. Technol., 48, 526-533, https://doi.org/10.1021/es4032562, 2014.

Tyndall, G. S. and Ravishankara, A. R.: Atmospheric oxidation of reduced sulfur species, Int. J. Chem. Kinet., 23, 483-527, https://doi.org/10.1002/kin.550230604, 1991.

Walker, C. F., Harvey, M. J., Smith, M. J., Bell, T. G., Saltzman, E. S., Marriner, A. S., McGregor, J. A., and Law, C. S.: Assessing the potential for dimethylsulfide enrichment at the sea surface and its influence on air-sea flux, Ocean Sci., 12, 1033-1048, https://doi.org/10.5194/os-12-1033-2016, 2016.

Warneke, C. and de Gouw, J. A.: Organic trace gas composition of the marine boundary layer over the northwest Indian Ocean in April 2000, Atmos. Environ., 35, 5923-5933, 2001.

Williams, T. L., Adams, N. G., and Babcock, L. M.: Selected ion flow tube studies of $\mathrm{H}_{3} \mathrm{O}^{+}\left(\mathrm{H}_{2} \mathrm{O}\right)_{0.1}$ reactions with sulfides and thiols, Int. J. Mass Spectrom., 172, 149-159, https://doi.org/10.1016/S0168-1176(97)00081-5, 1998.
Williams, J., Holzinger, R., Gros, V., Xu, X., Atlas, E., and Wallace, D. W. R.: Measurements of organic species in air and seawater from the tropical Atlantic, Geophys. Res. Lett., 31, L23S06, https://doi.org/10.1029/2004g1020012, 2004.

Williams, J., Custer, T., Riede, H., Sander, R., Jöckel, P., Hoor, P., Pozzer, A., Wong-Zehnpfennig, S., Hosaynali Beygi, Z., Fischer, H., Gros, V., Colomb, A., Bonsang, B., Yassaa, N., Peeken, I., Atlas, E. L., Waluda, C. M., van Aardenne, J. A., and Lelieveld, J.: Assessing the effect of marine isoprene and ship emissions on ozone, using modelling and measurements from the South Atlantic Ocean, Environ. Chem., 7, 171-182, https://doi.org/10.1071/EN09154, 2010.

Yang, M., Beale, R., Liss, P., Johnson, M., Blomquist, B., and Nightingale, P.: Air-sea fluxes of oxygenated volatile organic compounds across the Atlantic Ocean, Atmos. Chem. Phys., 14, 7499-7517, https://doi.org/10.5194/acp-14-7499-2014, 2014a.

Yang, M., Blomquist, B. W., and Nightingale, P. D.: Air-sea exchange of methanol and acetone during HiWinGS: Estimation of air phase, water phase gas transfer velocities, J. Geophys. Res.Oceans, 119, 7308-7323, https://doi.org/10.1002/2014jc010227, 2014b.

Yoch, D. C.: Dimethylsulfoniopropionate: Its Sources, Role in the Marine Food Web, and Biological Degradation to Dimethylsulfide, Appl. Environ. Microbiol., 68, 5804-5815, https://doi.org/10.1128/AEM.68.12.5804-5815.2002, 2002.

Yvon, S. A., Cooper, D. J., Koropalov, V., and Saltzman, E. S.: Atmospheric hydrogen sulfide over the equatorial $\mathrm{Pa}-$ cific (SAGA 3), J. Geophys. Res.-Atmos., 98, 16979-16983, https://doi.org/10.1029/92jd00451, 1993.

Zhou, X. and Mopper, K.: Photochemical production of lowmolecular-weight carbonyl compounds in seawater and surface microlayer and their air-sea exchange, Mar. Chem., 56, 201-213, https://doi.org/10.1016/S0304-4203(96)00076-X, 1997. 